\title{
The hidden Niemann-Pick type $C$ patient: clinical niches for a rare inherited metabolic
}

disease

Christian J Hendriksz, ${ }^{1}$ Mathieu Anheim, ${ }^{2}$ Peter Bauer, ${ }^{3}$ Olivier Bonnot, ${ }^{4}$ Anupam Chakrapani, ${ }^{5}$ Jean-Christophe Corvol, ${ }^{6}$ Tomas J De Koning, ${ }^{7}$ Anna Degtyareva, ${ }^{8}$ Carlo Dionisi-Vici, ${ }^{9}$ Sarah Doss,${ }^{10}$ Thomas Duning, ${ }^{11}$ Paola Giunti, ${ }^{12}$ Rosa Iodice,${ }^{13}$ Tracy Johnston, ${ }^{14}$ Dierdre Kelly, ${ }^{15}$ Hans-Hermann Klünemann, ${ }^{16}$ Stefan Lorenzl, ${ }^{17}$ Alessandro Padovani, ${ }^{18}$ Miguel Pocovi, ${ }^{19}$ Matthis Synofzik, ${ }^{20,21}$ Alta Terblanche,${ }^{22}$ Florian Then Bergh, ${ }^{23}$ Meral Topçu, ${ }^{24}$ Christine Tranchant, ${ }^{25}$ Mark Walterfang ${ }^{26}$, Christian E Velten, ${ }^{27}$ Stefan A $\mathrm{Kolb}^{227}$

\section{${ }^{1}$ Salford Royal NHS Foundation Trust, Manchester, UK and University of Pretoria, Pretoria,} South Africa; ${ }^{2}$ University of Strasbourg, Hautepierre Hospital, Strasbourg, France; ${ }^{3}$ Insititute of Medical Genetics and Applied Genomics, Tübingen University, Tübingen, Germany and CENTOGENE AG, Rostock, Germany; ${ }^{4} \mathrm{CHU}$ and University of Nantes, Nantes, France; ${ }^{5}$ Great Ormond St Hospital for Children, London, UK; ${ }^{6}$ Sorbonne University, UPMC and Hôpital Pitié-Salpêtrière, Department of Nervous System Diseases, Paris, France; ${ }^{7}$ University of Groningen, Groningen, the Netherlands; ${ }^{8}$ Federal State Budget Institution, Research Center for Obstetrics, Gynecology and Perinatology, Moscow, Russia; ${ }^{9}$ Bambino Gesù Children's Hospital, Rome, Italy; ${ }^{10}$ Charite University Medicine Berlin, Department of Neurology, Berlin, Germany; ${ }^{11}$ Münster University Hospital, Münster, Germany; ${ }^{12}$ University College London, Institute of Neurology, London, UK; ${ }^{13}$ University Federico II Naples, Naples, Italy; ${ }^{14}$ Birmingham Women's Hospital, Birmingham, UK; ${ }^{15}$ Birmingham Children's Hospital, Birmingham, UK; ${ }^{16}$ University Clinic for Psychiatry and Psychotherapy, 
Regensburg University, Regensburg, Germany; ${ }^{17}$ Ludwig Maximillian University, Munich, Germany, and Paracelus Medical University, Salzburg, Austria; ${ }^{18}$ Neurology Unit, Department of Clinical and Experimental Sciences, University of Brescia, Brescia, Italy; ${ }^{19}$ University of Zaragoza, IISA, Zaragoza, Spain; ${ }^{20}$ Department of Neurodegenerative Diseases, Hertie Institute for Clinical Brain Research, Tübingen, Germany; ${ }^{21}$ German Center for Neurodegenerative Diseases (DZNE), Tübingen, Germany; ${ }^{22}$ University of Pretoria, Pretoria, South Africa; ${ }^{23}$ University of Leipzig, Department of Neurology, Leipzig, Germany; ${ }^{24}$ Hacettepe University Children's Hospital, Ankara, Turkey; ${ }^{25} \mathrm{CHU}$ Strasburg, Strasburg, France; ${ }^{26}$ Royal Melbourne Hospital, Melbourne, Australia; ${ }^{27}$ Actelion Pharmaceuticals Ltd, Allschwil, Switzerland

*Drs Velten and Kolb contributed equally to this article

Correspondence: Professor Christian J Hendriksz, Department of Paediatrics and Child Health, Steve Biko Academic Unit, University of Pretoria, Pretoria, South Africa. Phone: 0161206 4365. Fax: 0161206 4036. Email: chris.henriksz@srft.nhs.uk; chris@fymcamedical.co.uk

\section{Manuscript statistics}

Abstract: 249 words

Body text: 6,919 words

Tables/Figures: none

References: 211 


\begin{abstract}
Background: Niemann-Pick disease type C (NP-C) is a rare, inherited neurodegenerative disease of impaired intracellular lipid trafficking. Clinical symptoms are highly heterogeneous, including neurological, visceral or psychiatric manifestations. The incidence of NP-C is underestimated due to under-recognition or misdiagnosis across a wide range of medical fields. New screening and diagnostic methods provide an opportunity to improve detection of unrecognized cases in clinical subpopulations associated with a higher risk of NP-C. Patients in these at-risk groups ('clinical niches') have symptoms that are potentially related to NP-C, but go unrecognized due to other, more prevalent clinical features and lack of awareness regarding underlying metabolic causes.
\end{abstract}

Methods: Twelve potential clinical niches identified by clinical experts were evaluated based on a comprehensive, non-systematic review of literature published to date. Relevant publications were identified by targeted literature searches of EMBASE and PubMed using key search terms specific to each niche. Articles published in English or other European languages up to 2016 were included.

Findings: Several niches were found to be relevant based on available data: movement disorders (early-onset ataxia and dystonia), organic psychosis, early-onset cholestasis/(hepato)splenomegaly, cases with relevant antenatal findings or fetal abnormalities, and patients affected by family history, consanguinity and endogamy. Potentially relevant niches requiring further supportive data included: early-onset cognitive decline, frontotemporal dementia, parkinsonism, and chronic inflammatory CNS disease. There was relatively weak evidence to suggest amyotrophic lateral sclerosis or progressive supranuclear gaze palsy as potential niches.

Conclusions: Several clinical niches have been identified that harbor patients at increased risk of NP-C. 


\section{Key words:}

Niemann-Pick disease type C (NP-C); diagnosis; screening; clinical niche; differential diagnosis; epidemiology; inborn errors of metabolism (IEM)

\section{Short title:}

Clinical niches for $N P-C$ 


\section{Introduction}

Niemann-Pick disease type $\mathrm{C}(\mathrm{NP}-\mathrm{C})$ is a rare, autosomal recessive, neurodegenerative disease caused by mutations in the NPC1 or NPC2 gene that lead to impaired intracellular lipid trafficking and excess storage of glycosphingolipids in the brain, liver and other tissues $[1,2,3,4]$. The disease shows a sporadic, panethnic occurrence, affecting between 1:89,000 and $1: 100,000$ individuals $[5,6,7,8,9]$.

NP-C can be regarded as a role model for other ultra-rare, inherited neurodegenerative diseases in a number of ways. Its true incidence is likely underestimated due to underrecognition and misdiagnosis. Patients with NP-C show extreme clinical heterogeneity in their symptom profiles, ages at disease onset, and rates of disease progression [10]. Presenting symptoms are often mild and non-specific. Multiple referrals are often required between primary care and a wide range of medical specialties including, but not limited to, pediatrics, adult neurology, hepatology, hematology and psychiatry. The diagnosis of NP-C therefore requires multidisciplinary clinical work-up and, ultimately referral to specialist centers with expertise in diagnostic laboratory tests $[10,11]$. As a result, many patients experience significant delays to diagnosis $[7,8,12,13]$.

The core neurological manifestations of NP-C affect movement (e.g., cerebellar ataxia), manipulation (e.g., dystonia, dysmetria), speech (dysarthria), and swallowing (dysphagia) $[11,14]$. Vertical supranuclear gaze palsy (VSGP) is considered highly characteristic, and seizures and gelastic cataplexy are also often reported $[10,15]$. Visceral symptoms include prolonged neonatal jaundice, hepatosplenomegaly, isolated splenomegaly and other cholestatic symptoms $[10,16,17]$. A range of psychiatric and behavioral disorders such as psychosis, bipolar disorder, developmental delay, and difficulties at school are frequently observed $[10,18,19]$. 
Certain clinical subpopulations are associated with a higher risk of NP-C compared with the general population. These 'clinical niches' comprise patients with symptoms that are potentially related to NP-C, but which go unrecognized due to other, more prevalent clinical features or a lack of emphasis and awareness regarding rare underlying metabolic causes (e.g., with complex neurological areas or in psychiatric practice). Targeted screening in cohorts of 'at risk' patients from such clinical niches may reveal previously unrecognized cases of NP-C. Fortunately, improved genetic analysis methods (e.g., next-generation sequencing [NGS] and gene panel testing) [9, 20, 21, 22, 23, 24], disease biomarkers (e.g., oxysterols, lysosphingolipids and bile acids) $[25,26,27,28,29,30]$, and clinical screening tools (the NP-C suspicion index [NPC-SI]) [7, 21, 31, 32, 33] are increasingly becoming available [21] and provide the opportunity to improve the detection of previously hidden cases of NP-C.

Expert consensus based on published evidence has identified the following potential clinical niches for NP-C: movement disorders (early-onset ataxia [EOA] and dystonia); early-onset cognitive decline (EOCD); frontotemporal dementia (FTD); parkinsonism; progressive supranuclear gaze palsy (PSP); organic psychosis; amyotrophic lateral sclerosis (ALS); unclear neuroinflammatory diseases; and hepatosplenomegaly or early-onset cholestasis. A family history of NP-C, and patients with antenatal findings or fetal abnormalities related to the disease also represent potential niches.

The following report provides a comprehensive review of all up-to-date information on known and putative clinical niches for NP-C. We aim to highlight clinical niches where future screening is considered likely to reveal new cases where it might previously have been overlooked. 


\section{Methods}

This non-systematic review of the literature was designed to provide an educational overview of current evidence regarding the occurrence of NP-C within 12 potential clinical niches and symptoms/methods that can be employed to aid in the identification of NP-C. This review was conducted according to a two-step process: 1) identification of potential clinical niches by simultaneous expert appraisal of medical fields in which new NP-C cases most often present, and specific diseases or disease areas within each relevant medical field that are most commonly associated with NP-C; and 2) assessment of identified niches based on comprehensive assessment of available, relevant evidence and expert opinion, including findings from clinical examination, biomarker evaluations and genetic mutation analyses as well as other diagnostic clues (e.g., cranial imaging assessments) observed in NP-C.

Data were identified by targeted literature searches of EMBASE and PubMed using key search terms specific to each niche. Articles published in English or other European languages up to 2016 were included. Priority was given to more recent articles.

Publication types considered suitable for inclusion included systematic reviews and metaanalyses, randomized controlled trials, epidemiological studies (case-control studies, cohort studies) and highly relevant narrative reviews. Given the rare nature of NP-C, case reports were also included. Once identified as relevant, all articles were screened for inclusion by indepth appraisal of data and other content. References from each included article were also assessed for inclusion.

The relevance of each clinical niche to NP-C was finally appraised, and classified as 'highly relevant', 'potentially relevant', 'not relevant' for NP-C based on the frequency of diagnosed patients in published reports, expert clinical experience, and other supporting information. 


\section{Familial aspects and ancestry}

A family history of NP-C and births from consanguineous parental relationships are widely acknowledged as powerful factors in predicting and detecting new cases of NP-C [10, 34, 35, 36, 37, 38]. In NP-C cohorts from the UK, Europe and Australia, 22-38\% of cases were related $[6,7,32]$. However, the high proportion of NP-C patients with compound heterozygote genotypes makes the study of genotype-phenotype correlations challenging [39, 40, 41]. NP-C symptoms can vary widely among family members, even in those with identical genetic mutations. Family studies in the UK and Czech Republic NP-C cohorts identified clinically asymptomatic siblings of patients with both early- and late-onset NP-C $[6,42]$.

Regions where consanguineous relationships are common (up to $34 \%$ of marriages in some regions) tend to be associated with a higher prevalence of autosomal recessive disorders, including NP-C [35, 36, 37, 43, 44, 45, 46, 47, 48, 49]. While no published studies have directly addressed the influence of endogamy on the occurrence of NP-C, 4/24 patients (17\%) diagnosed with NP-C were from consanguineous parents in a series of patients evaluated in Spain (Pocovi M, personal communication).

NP-C is a pan-ethnic disease, so endogamy is not considered such a relevant epidemiological influence on its occurrence. However, some mutations do tend to be localized to specific regions. For instance, regional genetic NP-C isolates are reported from the Greek Islands, the Rio Grande Valley in Colorado, and Nova Scotia [40, 50, 51, 52]. The incidence of NP-C in the endogamous population of Yarmouth County in Nova Scotia was approximately 1\% [53]. Sequencing methods for NPC1/NPC2 variants are expected to contribute valuable data on the influence of consanguinity and endogamy on NP-C and carrier genotypes in the future [9]. Whole-exome sequencing in 143 multiplex consanguineous families associated with 
autosomal-recessive neurogenesis disorders detected previously reported homozygous NPC2 mutations in a male index case (i.e., the first patient diagnosed within his family) as well as his sibling [54]. This was an intriguing finding as neither of these cases displayed progressive neurodegeneration or hepatosplenomegaly typical for their genotype, making it unlikely that they would have been detected based on clinical screening methods. To a degree, this finding casts some doubt on the variant classification applied. Targeted screening based on direct gene sequencing in 510 patients from the Turkish NP-C cohort identified two new patients with NP-C among family members of four index cases, and revealed an overall heterozygous NPC1/NPC2 mutation frequency of $22.7 \%$ (Topçu, personal communication).

Substantial published data show that family history is the strongest indicator for possible NPC cases, even among asymptomatic siblings. Parental genetic studies should be considered in index cases and their family members, where appropriate, in order to confirm homozygous status and identify/track heterozygote carriers $[6,7,8,10]$.

Genetic analyses, direct gene sequencing and close monitoring are strongly recommended in siblings of patients with confirmed NP-C in order to identify further, as-yet undetected cases $[8,10,11,55]$.

Biomarker screening, if available, could offer rapid diagnostic information in endogamous populations. In addition, if a particular region has a system in place to screen for rare metabolic diseases, it would be useful to include common NPC1 variants in the relevant gene panel in order to detect new cases and provide genetic counseling.

\section{Movement disorders - early-onset ataxia (EOA)}

Cerebellar ataxia is estimated to occur in $85-90 \%$ of NP-C patients, but in isolation it is not a specific clinical sign of the disease $[7,8,10,13,56]$. NP-C is not common among patients with pure cerebellar ataxia, or in patients with spastic presentations, and can be discounted in 
congenital, non-progressive ataxia $[13,56,57,58]$. Patients with NP-C fall into the diagnostic category of 'early-onset ataxia' (EOA) due to ataxia onset below 40 years of age $[13,31,56$, $59,60,61,62]$. Although frequent, EOA may be absent in the initial stages of the disease. In NP-C, EOA typically presents as a 'slow ataxia' that is frequently combined with dystonia, and in some patients, myoclonus [5, 58,63]. Gait itself may appear normal at early stages, but movements may be slowed and tandem gait may be well performed despite many years of disease progression [5].

Clinical diagnostic algorithms may aid in differential diagnosis, particularly among patients with unexplained ataxia $[31,60,64,65,66,67]$. Symptoms that are observed more frequently alongside ataxia in patients with NP-C compared with the general EOA population, which can thus serve as highly specific signs include: 1) cognitive decline/psychiatric disturbances; 2) VSGP; and 3) dystonia (specifically in the hands). A study in 133 EOA patients reported a 'two out of three rule' that reliably identified patients with unexplained EOA [31]. This simple screening method is based on the co-occurrence of EOA with at least two of the three specific concomitant NP-C symptoms mentioned above, and provides sensitivity and specificity for NP-C (90\% in both cases).

A clinical screening study in 24 patients with cerebellar ataxia and pre-senile cognitive decline identified four NP-C cases (17\% incidence) [56]. Genetic screening methods have been shown able to detect and diagnose NP-C among EOA patients in whom it might otherwise be missed during differential diagnosis $[56,68]$. A high-throughput gene sequencing study using an ataxia gene panel in 204 patients with EOA confirmed diagnosis of NP-C in six patients - a $2.9 \%$ incidence [20]. The total frequency of NPC1 gene variants was $8 / 192(4.17 \%)$, representing significant enrichment compared with a frequency of $1.6 \%$ in the control cohort $(\mathrm{p}=0.011)[20]$. 
Overall, published evidence showing a raised frequency of NP-C in the clinical EOA population indicates that unexplained EOA is a highly relevant clinical niche for the detection of new NP-C cases $[20,31,56]$.

\section{Movement disorders - dystonia}

Dystonia represents the third most common movement disorder and is acknowledged as one of the core neurological manifestations of NP-C, occurring in $40-50 \%$ of diagnosed cases $[13,59,63,69]$. In affected patients, dystonia contributes strongly to patient disability [14]. It can either be focal, affecting the hands, face or upper limbs, or more generalized, affecting gait $[10,69]$. Dystonia tends to occur later than other neurological signs during the course of NP-C, and has been reported most frequently in the juvenile and adolescent/adult neurological onset forms $[8,10,13,59]$.

The neuropathological changes underlying dystonia are complex. Dystonia is related to basal ganglia dysfunction, and correlates with pathology in the striatum [10, 61, 69]. Along with other genetic causes, dystonia associated with NP-C may also be related to cerebellar dysfunction $[70,71]$.

Over 42 hereditary disorders with associated neurodegeneration have dystonic symptoms, which can be categorized into two groups: monogenetic forms with assigned genetic loci (primary dystonias) and complex dystonia ('dystonia plus') syndromes [72]. 'Dystonia plus' syndromes, which include NP-C, Wilson disease, GLUT-1 deficiency and organic acidurias, comprise dystonia along with concomitant neurological and systemic features $[72,73]$.

Patients with dystonia plus syndrome, especially those displaying progressive dystonic signs and one or more of ataxia, myoclonus, VSGP, dysarthria, dysphagia, cognitive decline, psychiatric manifestations, cataplexy or splenomegaly, have an increased likelihood of NP-C $[32,60,61,63,74]$. Ataxia is a particularly common concomitant neurological sign [5, 31]. A 
young age at onset ( $<40$ years of age) can help distinguish dystonia related to NP-C from that associated with middle-age cervical torticollis. Focal dystonic features typically seen in NP-C include hand dystonia with wrist flexion and a forced (subtle) smile during speech due to dystonia of the jaw muscles (Iodice R, personal communication). Other visible symptoms such as facial grimacing and 'round the houses' sign (i.e., corrective horizontal saccades to accomplish upward voluntary pursuit movements) have also been described [75].

Based on observations from patients visiting specialist/tertiary referral clinics, it is estimated that up to $2 \%$ of dystonia patients could be diagnosed with NP-C, possibly even more [76]. While a 'genetics first' approach is sometimes recommended for diagnosis in cases of unexplained dystonia, initial biomarker-based methods can provide more rapid findings where underlying inherited metabolic diseases are suspected.

Dystonia is a commonly encountered yet complex neurological sign in clinical practice. Based on evidence to date, it is considered essential to increase awareness of NP-C as a possible underlying cause. The clinical dystonia population should be considered as a relevant clinical niche for further targeted screening for NP-C. However, the complexity of differential diagnosis related to dystonia requires that patient cohorts be clearly defined.

\section{Early-onset cognitive decline (EOCD)}

Pre-senile dementia or EOCD presents before the age of 65 years, and is being recognized more frequently [29]. Most cases of EOCD are related to Alzheimer disease (AD), but inherited neurodegenerative etiologies, including NP-C, are being reported more frequently as the underlying causes $[29,42,77]$.

NP-C shares a number of neuropathological features with AD and other dementias such as FTD and Lewy body dementia. Published data indicate a potential link between NPC1/NPC2 mutations and 'dementia plus' syndromes (i.e., where cognitive impairment is accompanied 
by other neuropsychiatric and systemic symptoms) [78]. Amyloid beta deposition, neurofibrillary tangles (NFTs), and tau-related pathology have also been observed in NP-C $[79,80,81]$, although it is not known whether these features are intrinsically linked with lysosomal trafficking defects, or represent more non-specific signs of neurodegeneration in NP-C $[82,83,84,85]$. Further, published data suggest a possible connection with apolipoprotein E4 (Apo E4), the principal cholesterol trafficking apolipoprotein in the brain, and a known risk factor associated with $\mathrm{AD}[86,87]$.

EOCD is observed during disease progression in almost all patients with adolescent/adultonset NP-C $[69,88,89]$. EOCD in adult-onset NP-C often presents with concomitant psychiatric signs $[7,10,19,57,69,74,88,90,91,92]$. As a result, NP-C is sometimes misdiagnosed as endogenous psychiatric disease, in particular schizophrenia [93]. EOCD is less commonly recognized among patients with childhood-onset NP-C, although intellectual developmental disorder, poor school performance and learning disabilities are often reported in affected children $[7,8,13,30,57,94]$.

Patients presenting with EOCD should be assessed for all cognitive domains, behavioral features, psychiatric history, and functional impairment [42]. Adults with NP-C may have a specific profile of cognitive deficits [89]: early signs of cognitive impairment in NP-C comprise reduced executive function, processing speed and verbal memory due to frontalsubcortical deficits $[69,89]$. As the disease progresses, further general cognitive decline and gradual loss of abilities to perform daily tasks occur alongside prominent memory and behavioral impairments $[10,94,95,96]$. Appropriate neuropsychological tests with elements of staging to disease severity may help to detect NP-C [89]. Trail Making tests A \& B and verbal fluency tests may prove useful in patients with mild disease. The Mini-Mental Status Examination [MMSE], Corsi Block-tapping, Find Similarities, and Clock Drawing Tests are appropriate for those with more advanced disease. 
There are only a few published NP-C screening studies among patients with EOCD. Data indicate that concomitant neurological symptoms can help to detect new cases. One genetic screening study indicated possible enrichment for NP-C among 250 patients with 'pre-senile cognitive decline' (i.e., EOCD) with and without psychiatric symptoms [76]. Another study in 24 patients with EOCD and degenerative ataxia identified four cases of NP-C (17\% incidence), which increased to $31 \%$ among patients who additionally showed VSGP [56]. The NPC-SI takes cognitive impairment into account, and could represent an effective screening method for NP-C in EOCD [32, 33, 97].

Despite the paucity of data from published screening studies, the clinical EOCD population is considered a relevant clinical niche for NP-C. Specific neuropsychological tests as well as the NPC-SI are considered applicable for screening among EOCD patients.

\section{Frontotemporal dementia (FTD)}

FTD is a leading cause of dementia in patients aged $<65$ years $[98,99]$, and shares a number of features in common with NP-C at the genetic, clinical and neuropathological levels, particularly among adult-onset cases. The behavioral variant of FTD is characterized by behavioral or cognitive deficits manifesting as early and progressive changes in personality (e.g., impulsivity, poor judgement), impaired language ability, and loss of organizational skills $[98,100,101]$. Patients with NP-C also often show a history of developmental problems and EOCD, and prominent executive dysfunction is frequently observed, particularly among patients with later-onset disease $[7,8,10]$.

Psychotic symptoms are often reported in both FTD and NP-C [7, 19, 102, 103, 104, 105, $106,107]$, and are associated with disrupted frontotemporal pathways and impaired frontalsubcortical connectivity [93, 108]. As in NP-C [69, 93, 102, 103, 109], psychosis in adults with FTD frequently leads to misdiagnosis with schizophrenia, schizoaffective disorder or 
bipolar disorder, often many years before a final diagnosis is confirmed $[106,110,111,112$, $113]$.

Approximately one-third of patients with FTD have a family history or confirmed predisposing genetic component $[29,114]$. Gene variants that have been linked with earlyonset neurodegenerative processes (i.e., those occurring at $<40$ years of age) common to both FTD and NP-C include C9orf72 $[115,116,117,118]$ and the progranulin gene, $P G R N$, which is associated with TAR DNA-binding rotein-43 (TDP-43)-related changes [29, 119]. Further, some forms of FTD can be listed alongside NP-C as tauopathies due to mutations in the MAPT tau gene on chromosome 17, and subsequent pathological tau accumulation $[120,121$, $122,123,124]$. Both NP-C and tau-related forms of FTD can display similar tau isoform profiles $[123,125]$.

Differential diagnosis of FTD versus NP-C is most likely to be required in adult patients who present with cognitive impairment and prominent executive dysfunction above 30 years of age, or in patients who present with major mental illness (e.g., schizophrenia-like symptoms, possibly with atypical signs) aged 15-30 years. Characteristic clinical manifestations that help distinguish NP-C from FTD and other forms of EOCD include both visceral and neurological symptoms [10]. Hepatosplenomegaly in NP-C has been proposed as a differential diagnostic indicator versus FTD and other etiologies associated with EOCD, although a lack of hepatosplenomegaly should not be taken to exclude NP-C. Abnormal saccadic eye movements (including VSGP) also serve as a strong indicator of possible NP-C. There are relatively few published data on $N P-C$ gene mutations from clinical screening studies in FTD patients. A genetic screening study including 133 FTD patients along with other neurodegenerative disorders did not detect any NPC1/NPC2 gene variants [22]. Findings from an ongoing genetic screening analysis of NPC1/NPC2 variants in 200 French FTD patients are awaited. 
Despite the lack of supportive data, the degree of symptomatic overlap and emerging evidence of genetic and pathophysiological commonalities between NP-C and FTD suggest that the clinical FTD population could be a relevant niche for the detection of NP-C.

\section{Parkinsonism}

Parkinsonism is clinically defined by tremor, bradykinesia/akinesia, rigidity, and postural instability and occurs in numerous sporadic and inherited neurological diseases. It is described in a range of tauopathies, and is often associated with EOCD [126]. However, parkinsonism can be difficult to discern among other prevailing neurological symptoms that are common in NP-C [127]. For instance, some patients may be treated with neuroleptic drugs, and subsequently develop iatrogenic parkinsonism.

A cohort study of movement disorders in adults with NP-C reported mild parkinsonism (bradykinesia, axial rigidity, hypomimia or isolated rest tremor) in approximately $10 \%$ of patients [69]. In this series, it did not represent a key diagnostic feature, and was usually detected only after systematic neurological examination [69].

Substantial evidence from genetic studies indicates a possible association between impaired lysosomal function and parkinsonism. A number of Parkinson disease (PD) genes (including SNCA, LRRK2, parkin, PINK1, and ATP13A2) are known to regulate lysosome-dependent pathways or lysosomal activity [128, 129, 130], while glucocerebrosidase (GBAl) mutations in GD patients and SMPD1 mutations have been associated with PD [131, 132, 133, 134, $135,136]$. With reference to NP-C, the autophagy-lysosome pathway may be a contributory pathophysiological factor for PD [137]. Autopsy evidence from NP-C patients indicated aberrant phosphorylation and aggregation of synuclein-alpha protein in Lewy bodies, along with typical tau-related neuropathological features [80, 138]. 
Several reports have suggested potential links between parkinsonism and NPC1/NPC2 mutations $[22,130,139]$. A case series reported parkinsonism syndrome in a total of four patients who had a single heterozygous NPC1 mutation [140]. A separate report of a heterozygous NPC1 mutation carrier with PD-like symptoms was also described [141]. However, a large-scale genetic screening study in 563 European PD patients identified single heterozygous pathological NPC1/NPC2 mutations in only $1.1 \%$ [22]. This was not significantly higher than in a control group $(n=7 / 846 ; 0.8 \%)$. No PD patients had homozygous NPC1/NPC2 mutations, although 16 variants of unknown significance were detected (12 in NPC1 and four in NPC2).

Overall, current evidence from clinical and genetic studies do not support parkinsonism as an important clinical niche for undetected cases of NP-C. More studies are needed to investigate whether NPC1/NPC2 mutations might be found in younger patients with parkinsonism. The prevalence of NP-C gene variants among other, non-European cohorts has also not yet been established.

\section{Progressive supranuclear gaze palsy (PSP)}

PSP is a neurodegenerative disease characterized by VSGP, gait disturbance, akinetic-rigid syndrome with levodopa unresponsiveness, dementia and premature death $[142,143]$, and is classified clinically as a form of atypical parkinsonism [144]. Clinical cases of NP-C have been misdiagnosed as PSP $[145,146]$. VSGP combined with cognitive decline is considered pathognomonic for NP-C [7, 8, 10, 147, 148, 149]. Voluntary vertical saccades are affected first in NP-C, followed by reduced slow eye pursuit movements and impaired horizontal saccades, and over time, full-blown VSGP develops due to increasing brainstem neurodegeneration $[150,151,152]$. Between $65 \%$ and $81 \%$ of patients with NP-C have impaired saccadic eye movements, which usually start in the late-infantile period $[10,13,32$, 
57], but it is suspected that these percentages are underestimations due to lack of proper evaluation. The early impairment of vertical saccades, often preceding other motor symptoms, indicates a delicate sensitivity of the rostral interstitial nucleus of the medial longitudinal fasciculus (riMLF) to neurodegenerative decay in NP-C [148, 153]. The vulnerability of riMLF neurons to NP-C pathophysiology is not yet fully understood, but might offer a good window in the future to study the specific and early pathophysiology underlying NP-C neurodegeneration.

Approximately $40 \%$ of cases of PSP are associated with underlying tauopathic changes, and in this respect share pathophysiological aspects common to NP-C [142, 154, 155]. Many patients also show overlaps in the profile of clinical symptoms, particularly movement disorders and cognitive impairments $[120,142,156]$. This can present a challenge in differential diagnosis [146]. A key distinguishing factor between the two conditions is age at onset; PSP usually starts in the fifth to the seventh decade of life, while NP-C generally presents much earlier on.

The occurrence of NP-C within the clinical PSP population is unknown. A case series in four PSP patients reported filipin test results consistent with NP-C, but no genetic confirmation was established [58]. A genetic screening study in multiple neurodegenerative diseases, including 94 patients with PSP, did not detect any NPC1/NPC2 variants [22]. Given the clinical similarities between NP-C and PSP, it is recommended that patients who present with PSP-like clinical signs before the ages typically associated with PSP should be tested for NPC [157]. More specifically, the presence of cerebellar ataxia, EOCD with onset before 50 years of age, or visceral symptoms such as splenomegaly can help distinguish between PSP and NP-C $[10,66,144]$. Methods for assessing ocular motor abnormalities characteristic of PSP are available $[158,159]$. Published data suggest that analysis of cerebrospinal fluid 
(CSF) truncated tau levels may also provide useful information for the differential diagnosis $[160,161]$

No confirmed NP-C cases have been identified through any screening approaches in PSP to date. While PSP is considered less relevant as a potential clinical niche for undetected NP-C patients, further investigations in PSP are still considered scientifically reasonable.

\section{Organic psychosis}

NP-C, along with several other inborn errors of metabolism (IEMS), is among a large number of diseases associated with organic psychiatric disturbances [95, 108, 162, 163]. Psychiatric symptoms are most commonly observed in adolescent/adult-onset NP-C, and have been reported in up to $55 \%$ of patients in this category $[7,8,19,57,69,88,91]$. Notably, symptoms are often reported at initial presentation $[69,93]$. In a study of 87 NP-C patients from the US national NP-C cohort, psychiatric problems were significantly more common among patients aged $\geq 18$ years $(45 \%)$ compared with those aged $<18$ years $(11 \% ; \mathrm{p}<0.01)$ [57].

As seen in many diseases associated with organic psychiatric symptoms, NP-C patients who initially present in psychiatric practice may remain improperly diagnosed, or go undiagnosed, for years due to heterogeneous clinical features, limited awareness of NP-C as a possible underlying condition, or the long time frame over which the disease progresses [87]. Psychiatric symptoms may therefore be the only manifestation of NP-C for years before other symptoms become apparent $[93,164]$. Consequently, patients who present to psychiatrists often experience significant delay before a definitive diagnosis of NP-C [7, 93, 108, 162]. Psychotic symptoms are the most frequent psychiatric manifestations reported in NP-C [19, $35,47,52]$. and often manifest as schizophrenia-like symptoms comprising paranoid delusions, auditory hallucinations, and disorganized thoughts $[7,74,93,103,162,164]$. 
Depression, bipolar disorder and obsessive-compulsive disorder are also reported [10, 19, 108, 163]. A retrospective survey of psychiatric presentations among French adult NP-C patients who underwent psychiatric evaluation reported psychotic symptoms in 55\%, and half had a psychiatric diagnosis: schizophrenia in $27 \%$ and depression in $23 \%$ [19]. A systematic literature analysis of psychiatric manifestations in 58 NP-C patients who were mostly adolescents or adults at neurological onset reported psychotic symptoms in $62 \%$ overall, and behavior- and mood-related manifestations in 52\% and 38\%, respectively [18]. Notably, $87 \%$ of patients in the US NP-C cohort had learning difficulties, which are often also encountered in psychiatric practice [57].

There are few published data from genetic screening studies of NP-C in psychiatric patient populations. However, the 'ZOOM' study, which systematically screened for NP-C gene mutations in 250 patients with neurological and psychiatric symptoms, identified three (1.2\%) new NP-C cases and $12(4.8 \%)$ more patients who were classified as 'NP-C uncertain' [76]. The detection rate in this study was substantially higher than the general population, and suggests that screening for NP-C in selected neuropsychiatric populations may result in the identification of more new cases.

Vigilance for atypical psychiatric signs, neurological manifestations, and visceral symptoms can aid in the differential diagnosis of NP-C versus primary psychiatric conditions and other organic causes [162]. Readily recognizable psychiatric signs that should trigger the suspicion of underlying organic disease in patients with schizophrenia-like symptoms include: acute confusional states; a preponderance of visual hallucinations over auditory hallucinations; catatonia; early or acute onset of psychiatric symptoms; fluctuating symptoms; antipsychotic treatment resistance; and sensitivity to low doses of high-potency neuroleptics $[7,95,103$, $162,165]$. Clinical diagnostic algorithms provide a framework for the detection of hidden 
NP-C (amongst other IEMs) in psychiatric patient populations [95]. The NPC-SI may also be useful as a clinical screening tool in psychiatry [32].

Published evidence indicates that organic psychosis is an important clinical niche for NP-C screening. Improved awareness among psychiatrists of IEMs as possible causes of psychiatric symptoms is key to achieving early detection [91].

\section{Amyotrophic lateral sclerosis (ALS)}

ALS is a late-onset motor neuron disease featuring progressive neurodegeneration and a degree of symptomatic overlap with NP-C. Both NP-C and ALS can be associated with movement disorders, dysphagia, dysarthria, ophthalmoplegia and cognitive impairment/dementia $[166,167]$. Between 5 and $10 \%$ of ALS cases are inherited in an autosomal dominant fashion [168]. The two conditions have a number of pathophysiological features in common, including tau-associated neurofibrillary tangles [167] and changes in intracellular second messengers [82, 169].

Despite clinical and neuropathological features held in common between ALS and NP-C, there are few published data indicating any firm clinical links. ALS is most common in individuals aged $\geq 60$ years, but also occurs in younger patients $[170,171]$. Nevertheless, based on the distinct overlap in clinical symptomatology in the two conditions (e.g., mild upper-girdle motor impairment with predominant VSGP, gait ataxia, dystonia or psychiatric features), it is considered most likely that NP-C would be detected among patients with young-onset ALS. In terms of differential diagnosis, electrophysiological testing is a widely used method for assessing motor neuron disease specific to ALS [172]. However, electrophysiological tests in patients with NP-C generally provide mixed findings [173]. Signs of acute denervation are often observed in ALS but are not common in NP-C. 
Only one report of genetic screening for NP-C in ALS has been published to date. Wholeexome sequencing using NGS was conducted in two siblings who were suspected to have ALS, but were subsequently diagnosed with NP-C [23].

Overall, there is a paucity of published data on the occurrence of NP-C in the ALS population. Thus, without additional evidence, ALS cannot currently be considered a relevant clinical niche for NP-C.

\section{Chronic inflammatory CNS disease (e.g., multiple sclerosis)}

Multiple sclerosis (MS) occurs in approximately 180/100,000 in Central Europe and North America [174]. Common symptoms, which typically start during early adulthood and follow a relapsing or progressive course, include ataxia, optic neuritis, sensory disturbance, pyramidal weakness, bladder dysfunction, fatigue, insidious cognitive deterioration, and depression/euphoria.

Patients are routinely diagnosed with MS based on CSF analysis demonstrating intrathecal immunoglobulin synthesis, white-matter abnormalities on cerebral MRI, and evidence of demyelination $[175,176,177]$. In patients who present with typical clinical signs, the differential diagnosis is reasonably limited [175], but in less typical cases a wide range of rare causes must be considered.

There are several overlaps in the clinical symptomatology of NP-C and MS, particularly in terms of movement disorders (ataxia) [20, 178], oculomotor disturbances (slow saccades, impaired saccadic pursuit and VSGP) [56, 148, 151, 175, 179], and cognitive deficits [180, 181]. In addition, both NP-C and MS share a number of neuroinflammatory changes. Altered CSF neuroinflammatory cytokine marker levels, microglial activation and the release of neurotoxic cytokines have been reported in both conditions [182, 183, 184]. These are 
thought to be central pathogenetic features of MS, while their role in NP-C is not clear at present.

Screening for NP-C in patients with presumed MS is appropriate when cranial MRI findings are largely normal (i.e., not fulfilling accepted imaging criteria for MS), as is often the case in late-onset NP-C $[175,178,185]$. Similarly, the absence of chronic-inflammatory features from CSF analysis, persistent inefficacy of disease-modifying MS treatments, or normal visual evoked potentials should initiate further evaluation of potential differential diagnoses $[173,175]$.

One case of an adult patient with prominent progressive dementia and multiple non-specific neurological signs has been reported as 'adult-onset NP-C mimicking features of MS [186]. Neurological symptoms included slight bilateral ataxia in the legs and mild saccadic dysmetria, concomitant with behavioral, mood and early-onset cognitive impairments. While the patient was initially diagnosed with MS based on clinical findings, CSF analysis, and cranial MRI, persistent splenomegaly prompted further investigations that led to a diagnosis of NP-C [186].

Despite anecdotal evidence there are no robust published data to support MS as a relevant clinical niche for detecting NP-C. Further studies are required to develop the understanding of potentially overlapping disease mechanisms.

\section{Cholestasis and hepatosplenomegaly in early-infantile patients}

The earliest presentation of NP-C during infancy may be with non-immune hydrops and fetal ascites or isolated splenomegaly [7, 8, 10, 187]. Infants may be born with prolonged, unexplained neonatal jaundice lasting $>2$ weeks, and acute liver failure $[7,10,16,17]$. These symptoms precede any obvious neurological symptoms in the course of NP-C $[6,7,8,10$, 13]. 
The differential diagnosis of cholestatic symptoms in pediatric patients is extensive [188, $189,190,191,192,193]$, and presents challenges for the identification of NP-C in pediatric liver units [194]. However, the vast majority, if not all patients with NP-C will have splenomegaly at birth. Pulmonary disease is a rare concomitant complication, but is another strong clinical indicator. Portal hypertension needs to be excluded in older children who present with cholestatic symptoms [17, 193].

NP-C has been reported as one of the most common genetic causes of liver disease during infancy $[6,10,195,196]$. For example, in a UK study of infants investigated for acute liver failure, three cases of NP-C (8\%) were identified among 37 patients with an IEM [195]. In a North American liver unit, NP-C alone accounted for approximately $8 \%$ of general pediatric patients who were investigated for neonatal cholestasis $(n=40)$ [196].

As visceral symptoms precede neurological symptoms in the course of NP-C, neonates and infants who present with visceral symptoms and concomitant neurological signs such as developmental delay, hypotonia, and gelastic cataplexy, are clear candidates for additional diagnostic testing $[6,10]$. An early-onset NPC-SI facilitates the identification of patients with suspected NP-C aged $\leq 4$ years of age, based on combinations of some of these key symptoms [197]. Patients who exhibit both cholestatic symptoms and splenomegaly show high SI scores (indicating strong suspicion of NP-C).

Genetic screening studies have demonstrated a possible enrichment for NP-C among cholestatic infants in the general clinical population. An NGS study with microarray resequencing analysis in 222 infants with cholestasis, acute liver failure, hepatomegaly or splenomegaly identified autosomal recessive IEMs in 19 patients (9\%), and confirmed NP-C in one $(0.5 \%)$ [198]. Seven $(3 \%)$ heterozygous individuals with single pathogenic NPC1 variants were also reported [198]. In a study based on massively parallel sequencing of 93 
genes associated with inherited cholestatic disorders in infants, a novel pathogenic NPC1 mutation was identified [24, 199].

Overall, data indicate that patients with early cholestasis/prolonged neonatal jaundice or hepatosplenomegaly represent a highly relevant clinical niche for the detection of NP-C.

\section{Antenatal findings, fetal abnormalities and newborn screening}

Prenatal diagnosis and newborn screening for LSDs have become topics of intense research in recent years due to the development of targeted treatment options, improved screening methods and the availability of biomarkers [30, 200, 201, 202, 203].

In terms of early-infantile clinical symptoms, prolonged neonatal jaundice, splenomegaly (with or without hepatomegaly) and fetal ascites (hydrops fetalis) detected during antenatal assessment should arouse suspicion of NP-C, even in the absence of a family history [204, 205]. To date, 15 cases of antenatal-onset NP-C were reported: all featured splenomegaly, ascites, hepatomegaly or placentomegaly at a median gestational age of 24 weeks [205]. Unexplained fetal hydrops and signs of liver failure may be viewed as additional factors to raise suspicion of NP-C [10]. These clinical symptoms are nonspecific, and must be considered alongside other causes during differential diagnosis [24, 189, 194, 198]. The early-onset NPC-SI is available to support diagnosis based on clinical symptomatology in infants aged $\leq 4$ years $[32,197]$.

As NP-C is inherited in an autosomal recessive manner, prenatal diagnosis is available to affected families if they wish, for the detection of NP-C among siblings of first cases to be diagnosed. Traditionally, filipin staining based on chorionic villus sampling was recommended for antenatal diagnosis of NP-C [10, 11, 189]. However, as genetic analysis is now routinely used in initial diagnostic workup, causative mutations are usually known in index cases, and mutation analysis based on chorionic villus sampling or amniocentesis is the 
method of choice for antenatal diagnosis. Simple testing for free fetal DNA in maternal blood may one day allow prenatal screening in affected families, thus avoiding invasive prenatal diagnostic procedures and risk of miscarriage [206]. For previously undiagnosed prenatalonset and neonatally presenting cases, it is likely that plasma and dried blood spot (DBS) biomarkers will become the preferred method for postnatal diagnosis and newborn screening of NP-C, particularly in cases with a strong clinical suspicion of NP-C, where only minor blood sample volumes are available [21, 30, 55, 189, 202, 207, 208].

For newborn screening, NGS and multi-gene panels will make rapid, wide-ranging genetic screening more accessible [21, 24, 198]. However, ethical concerns and legal restrictions may preclude genetic newborn screening in some countries [21, 209].

Overall, patients with certain fetal abnormalities are considered to be a highly relevant clinical niche for NP-C screening, and multi-panel approaches (e.g., with biomarkers) may prove especially helpful. While newborn screening offers tangible benefits in terms of early detection and diagnosis, more consideration of both practical and ethical implications is required.

\section{Discussion}

In this review, twelve clinical niches considered to have a potential of harboring patients with an increased risk of NP-C were examined in detail via the published evidence and expert opinion. Niches with strong evidence to support their high relevance to detecting and diagnosing NP-C where it has previously been overlooked include: antenatal findings, fetal abnormalities and newborn screening, movement disorders (EOA and dystonia), organic psychosis, cholestasis and hepatosplenomegaly in early-infantile patients, and patients affected by familial aspects and ancestry. Niches thought to be of potential relevance, where further data are required or studies are still ongoing include: EOCD, FTD, parkinsonism, and 
chronic inflammatory CNS disease such as MS. Only relatively weak evidence was available to suggest an increased likelihood of detecting NP-C in ALS and PSP niches.

It is possible that other putative clinical niches may also yield further valuable data (e.g., other tauopathies, early-onset AD, multiple system atrophy, Huntington-like disease, treatment-resistant epilepsy, patients with one identified NPC1 or NPC2 mutation). Screening initiatives within locally existing niche cohorts represent a good starting point for future studies.

Future screening studies in clinical niches identified here as carrying an increased risk of NP$\mathrm{C}$ would address the following goals: 1) confirm whether NPC1/NPC2 gene mutations underlie unclear symptomatology in suspected cases; 2) exclude NP-C in patients where, despite unclear symptomatology, it is not present; and 3) aid secondary identification of other relevant rare diseases for differential diagnostic purposes. The identification of hidden NP-C cases associated with unclear symptoms in at-risk patient groups is important because a targeted therapy (miglustat) is available that is of most benefit where treatment is initiated early on in the disease course $[10,11,210]$.

This review of published evidence serves to highlight that, as in most ultra-rare diseases, consideration of clinical symptom combinations/co-morbidities relevant to each niche is a vital aspect for the detection of NP-C. For instance, throughout all niches where clinical neurological or psychiatric manifestations form part of the core symptomatic profile, historical cholestatic symptoms or hepatosplenomegaly, or ongoing visceral symptoms, whether symptomatic or not, are consistently acknowledged as strong factors in raising suspicion of NP-C. The NPC-SI and the early-onset NPC-SI allow a systematic approach to initial screening based on clinical symptomatology $[32,197]$. Easy-to-apply and readily available tests such as oculomotor examinations and cranial MRI can add valuable further 
information (e.g., in organic psychosis, dystonia, EOCD, and unclear neuroinflammatory disease).

Rapid, convenient and cost-effective biomarker-based methods for NP-C screening and diagnosis are increasingly becoming available in specialized laboratories worldwide [21]. Numerous studies have demonstrated the utility of plasma oxysterols as a primary diagnostic test for NP-C across a number of patient cohorts [21, 25, 26, 211]. Lysosphingolipids have also been shown to be effective biomarkers for NP-C [21, 27, 28], additionally providing the advantage of adaptation to robust high-throughput setups using DBS filter cards and multiplex analysis of NP-C along with other sphingolipidoses (e.g., GD and Fabry disease). It is thought likely that combined analysis of both oxysterol and lysosphingolipid profiles will help to improve diagnostic specificity for NP-C versus other IEMs. Bile acid assays represent a promising additional biomarker option for NP-C screening/diagnosis $[21,29,30]$. While limited published data are available, an advantage of lysosphingolipid and bile acid-based methods is that they can be conducted in plasma samples or DBS. Studies utilizing some of these biomarker methods are ongoing in some clinical niches addressed in this review (e.g., in dystonia, PSP, and early-onset cholestasis).

Improvements in the speed, accuracy, accessibility and cost-effectiveness of NPC1/NPC2 analysis over the last decade have led to genetic analysis now being considered as the primary means of confirming NP-C diagnosis [21]. While Sanger-based cDNA and gDNA sequencing remains the mainstay of NP-C genetic analysis, NGS techniques, which can be adapted to gene panels and used in whole-exome and whole-genome sequencing, are increasingly being applied [21]. However, due to certain error rates inherent in all genetic approaches, complementary testing by MLPA and quantitative PCR can provide further proof $[21,76]$. Data from studies utilizing NGS in certain NP-C clinical niches covered in this review have already been published (e.g., in EOA, ALS and early-onset cholestasis) [20, 23, 
24]. Further data on the application of these techniques in prenatal testing and newborn screening/diagnosis are awaited [21].

\section{Conclusions}

Several clinical niches have been identified that harbor patients at increased risk of NP-C. There is a continued need for improved awareness of NP-C as a possible underlying cause of symptoms commonly encountered in these niches. Increased vigilance for combinations of characteristic clinical disease manifestations, along with the inclusion of NP-C in biomarker and genetic screening assays, could reduce diagnostic delays and result in earlier initiation of targeted therapy for patients with NP-C.

\section{Transparency section}

\section{Funding}

This review was funded by Actelion Pharmaceuticals Ltd., Allschwil, Switzerland.

\section{Financial/other interests}

From Actelion Pharmaceuticals Ltd.: travel expenses AC, AD, MT, OB, CL, MW, HHK, MP, MS, PB; research funding PB, TD, TdK, RI, FT-B, OB, CL, MW; consultancy fees PB, MT, OB, OB, CL, MW, HHK; Speaker honoraria PB, MP, MS. MA has received speaker honoraria and travel expenses from Actelion Pharmaceuticals Ltd., Abbvie, TEVA, and UCB. $\mathrm{J}-\mathrm{CC}$ has received speaker honoraria from Abbvie, travel grants from Abbvie, research funding from Actelion Pharmaceuticals Ltd, Ipsen, and the Michael J Fox Foundation, and consultancy fees from BMS, Zambon, Pfizer, Amarantus, Clevexel, and Abbvie. CD-V has received research grants, investigator fees, speaker honoraria, and travel expenses from 
Actelion Pharmaceuticals Ltd., Sanofi Genzyme, Orphan Europe, and Nutricia. SD has received research funding, speaker honoraria, and travel expenses by Actelion Pharmaceuticals Ltd., and research funding from TEVA. CJH is Director of FYMCA Medical Ltd., has received consultancy fees and travel expenses from Actelion Pharmaceuticals Ltd., Alexion, Amicus, Biomarin, Inventiva, Sanofi Genzyme, and Shire, and has undertaken paid research on behalf of Actelion Pharmaceuticals Ltd., Amicus, Biomarin, Sanofi Genzyme and Shire. SL has received consultancy fees and travel expenses from Actelion Pharmaceuticals Ltd, TEVA, Boehringer, Gruenenthal, and UCB6e. AP has received research funding, consultancy fees and travel expenses from Actelion Pharmaceuticals Ltd., Eli-Lilly, GE Health, and Lundbeck. CT has received speaker honoraria and travel expenses from Abbvie, Zambon, TEVA, and UCB. CV and SK are employees of Actelion Pharmaceuticals Ltd. TJ, PG and AT have no conflicts to declare.

\section{Author contributions}

All authors have made substantial contributions to the acquisition, analysis, or interpretation of data, had writing input and provided critical revision of the manuscript, and provided final approval of the version to be published. All authors agree to be accountable for all aspects of the work.

\section{Acknowledgements}

Matthew Reilly at InTouch Medical Ltd provided medical writing support in the preparation of this manuscript, paid for by Actelion Pharmaceuticals Ltd. 


\section{References}

1. Vanier MT. Complex lipid trafficking in Niemann-Pick disease type C. J Inherit Metab Dis. 2015;38:187-99. Epub 2014/11/27.

2. Vanier MT, Millat G. Niemann-Pick disease type C. Clin Genet. 2003;64:269-81. Epub 2003/09/17.

3. te Vruchte D, Lloyd-Evans E, Veldman RJ, Neville DC, Dwek RA, Platt FM, van Blitterswijk WJ, Sillence DJ. Accumulation of glycosphingolipids in Niemann-Pick C disease disrupts endosomal transport. J Biol Chem. 2004;279:26167-75. Epub 2004/04/14.

4. Lloyd-Evans E, Platt FM. Lipids on trial: the search for the offending metabolite in Niemann-Pick type C disease. Traffic. 2010;11:419-28. Epub 2010/01/12.

5. Mengel E, Klünemann HH, Lourenco CM, Hendriksz CJ, Sedel F, Walterfang M, Kolb SA. Niemann-Pick disease type C symptomatology: an expert-based clinical description. Orphanet J Rare Dis. 2013;8:166. Epub 2013/10/19.

6. Jahnova H, Dvorakova L, Vlaskova H, Hulkova H, Poupetova H, Hrebicek M, Jesina P. Observational, retrospective study of a large cohort of patients with Niemann-Pick disease type $\mathrm{C}$ in the Czech Republic: a surprisingly stable diagnostic rate spanning almost 40 years. Orphanet J Rare Dis. 2014;9:140. Epub 2014/09/23.

7. Walterfang M, Bonnot O, Mocellin R, Velakoulis D. The neuropsychiatry of inborn errors of metabolism. J Inherit Metab Dis. 2013;36:687-702. Epub 2013/05/24.

8. Vanier MT. Niemann-Pick disease type C. Orphanet J Rare Dis. 2010;5:16. Epub 2010/06/08.

9. Wassif CA, Cross JL, Iben J, Sanchez-Pulido L, Cougnoux A, Platt FM, Ory DS, Ponting CP, Bailey-Wilson JE, Biesecker LG, Porter FD. High incidence of unrecognized visceral/neurological late-onset Niemann-Pick disease, type $\mathrm{C}$ 1, predicted by analysis of massively parallel sequencing data sets. Genet Med. 2016;18:41-8. Epub 2015/03/13.

10. Patterson MC, Hendriksz CJ, Walterfang M, Sedel F, Vanier MT, Wijburg F, the NP-C Working Group. Recommendations for the diagnosis and management of NiemannPick disease type C: an update. Mol Genet Metab. 2012;106:330-44. Epub 2012/05/11. 
11. Wraith JE, Baumgartner MR, Bembi B, Covanis A, Levade T, Mengel E, Pineda M, Sedel F, Topcu M, Vanier MT, Widner H, Wijburg FA, Patterson MC, the NP-C Working Group. Recommendations on the diagnosis and management of Niemann-Pick disease type C. Mol Genet Metab. 2009;98:152-65. Epub 2009/08/04.

12. Imrie J, Dasgupta S, Besley GT, Harris C, Heptinstall L, Knight S, Vanier MT, Fensom AH, Ward C, Jacklin E, Whitehouse C, Wraith JE. The natural history of Niemann-Pick disease type C in the UK. J Inherit Metab Dis. 2007;30:51-9. Epub 2006/12/13.

13. Patterson MC, Mengel E, Wijburg FA, Muller A, Schwierin B, Drevon H, Vanier MT, Pineda M. Disease and patient characteristics in NP-C patients: findings from an international disease registry. Orphanet J Rare Dis. 2013;8:12. Epub 2013/01/18.

14. Iturriaga C, Pineda M, Fernandez-Valero EM, Vanier MT, Coll MJ. Niemann-Pick C disease in Spain: clinical spectrum and development of a disability scale. J Neurol Sci. 2006;249:1-6. Epub 2006/07/04.

15. Zarowski M, Steinborn B, Gurda B, Dvorakova L, Vlaskova H, Kothare SV. Treatment of cataplexy in Niemann-Pick disease type $\mathrm{C}$ with the use of miglustat. Eur J Paediatr Neurol. 2011;15:84-7. Epub 2010/03/09.

16. Imrie J, Wraith JE. Isolated splenomegaly as the presenting feature of Niemann-Pick disease type C. Arch Dis Child. 2001;84:427-9. Epub 2001/04/24.

17. Kelly DA, Portmann B, Mowat AP, Sherlock S, Lake BD. Niemann-Pick disease type $\mathrm{C}$ : diagnosis and outcome in children, with particular reference to liver disease. $\mathrm{J}$ Pediatr. 1993;123:242-7. Epub 1993/08/01.

18. Bonnot O, Klünemann HH, Velten C, Torres Martin JV, Walterfang M. Systematic review of psychiatric signs associated with Niemann Pick disease type $\mathrm{C}$ and analysis of symptom groups. J Clin Psych. 2016. [submitted]

19. Maubert A, Hanon C, Sedel F. [Psychiatric disorders in adult form of Niemann-Pick disease type C]. L'Encephale. 2016;42:208-13. Epub 2016/01/05.

20. Synofzik M, Harmuth F, Stampfer M, Muller Vom Hagen J, Schols L, Bauer P. NPC1 is enriched in unexplained early onset ataxia: a targeted high-throughput screening. $\mathbf{J}$ Neurol. 2015;262:2557-63. Epub 2015/09/05.

21. Vanier MT, Gissen P, Bauer P, Coll MJ, Burlina A, Hendriksz CJ, Latour P, Goizet C, Welford RW, Marquardt T, Kolb SA. Diagnostic tests for Niemann-Pick disease type C (NP-C): A critical review. Mol Genet Metab. 2016;118:244-54. Epub 2016/06/25. 
22. Zech M, Nubling G, Castrop F, Jochim A, Schulte EC, Mollenhauer B, Lichtner P, Peters A, Gieger C, Marquardt T, Vanier MT, Latour P, Klünemann H, Trenkwalder C, Diehl-Schmid J, Perneczky R, Meitinger T, Oexle K, Haslinger B, Lorenzl S, Winkelmann J. Niemann-Pick $\mathrm{C}$ disease gene mutations and age-related neurodegenerative disorders. PLoS One. 2013;8:e82879. Epub 2014/01/05.

23. Alavi A, Nafissi S, Shamshiri H, Nejad MM, Elahi E. Identification of mutation in NPC2 by exome sequencing results in diagnosis of Niemann-Pick disease type C. Mol Genet Metab. 2013;110:139-44. Epub 2013/06/25.

24. Herbst SM, Schirmer S, Posovszky C, Jochum F, Rodl T, Schroeder JA, Barth TF, Hehr U, Melter M, Vermehren J. Taking the next step forward - Diagnosing inherited infantile cholestatic disorders with next generation sequencing. Molecular and Cellular Probes. 2015;29:291-8. Epub 2015/03/17.

25. Porter FD, Scherrer DE, Lanier MH, Langmade SJ, Molugu V, Gale SE, Olzeski D, Sidhu R, Dietzen DJ, Fu R, Wassif CA, Yanjanin NM, Marso SP, House J, Vite C, Schaffer JE, Ory DS. Cholesterol oxidation products are sensitive and specific bloodbased biomarkers for Niemann-Pick C1 disease. Sci Transl Med. 2010;2:56ra81. Epub 2010/11/05.

26. Jiang X, Sidhu R, Porter FD, Yanjanin NM, Speak AO, te Vruchte DT, Platt FM, Fujiwara H, Scherrer DE, Zhang J, Dietzen DJ, Schaffer JE, Ory DS. A sensitive and specific LC-MS/MS method for rapid diagnosis of Niemann-Pick C1 disease from human plasma. J Lipid Res. 2011;52:1435-45. Epub 2011/04/27.

27. Welford RW, Garzotti M, Marques Lourenco C, Mengel E, Marquardt T, Reunert J, Amraoui Y, Kolb SA, Morand O, Groenen P. Plasma lysosphingomyelin demonstrates great potential as a diagnostic biomarker for Niemann-Pick disease type $\mathrm{C}$ in a retrospective study. PLoS ONE. 2014;9:e114669. Epub 2014/12/06.

28. Giese AK, Mascher H, Grittner U, Eichler S, Kramp G, Lukas J, te Vruchte D, Al Eisa N, Cortina-Borja M, Porter FD, Platt FM, Rolfs A. A novel, highly sensitive and specific biomarker for Niemann-Pick type $\mathrm{C} 1$ disease. Orphanet J Rare Dis. 2015;10:78. Epub 2015/06/18.

29. Mazzacuva F, Mills P, Mills K, Camuzeaux S, Gissen P, Nicoli ER, Wassif C, Te Vruchte D, Porter FD, Maekawa M, Mano N, Iida T, Platt F, Clayton PT. Identification 
of novel bile acids as biomarkers for the early diagnosis of Niemann-Pick $\mathrm{C}$ disease. FEBS Lett. 2016: 590(11):1651-62. Epub 2016/05/04.

30. Jiang X, Sidhu R, Mydock-McGrane L, Hsu FF, Covey DF, Scherrer DE, Earley B, Gale SE, Farhat NY, Porter FD, Dietzen DJ, Orsini JJ, Berry-Kravis E, Zhang X, Reunert J, Marquardt T, Runz H, Giugliani R, Schaffer JE, Ory DS. Development of a bile acid-based newborn screen for Niemann-Pick disease type C. Sci Transl Med. 2016;8:337ra63. Epub 2016/05/06.

31. Synofzik M, Fleszar Z, Schols L, Just J, Bauer P, Torres Martin JV, Kolb S. Identifying Niemann-Pick type $\mathrm{C}$ in early-onset ataxia: two quick clinical screening tools. J Neurol. 2016;263:1911-8. Epub 2016/06/18.

32. Wijburg FA, Sedel F, Pineda M, Hendriksz CJ, Fahey M, Walterfang M, Patterson MC, Wraith JE, Kolb SA. Development of a suspicion index to aid diagnosis of NiemannPick disease type C. Neurology. 2012;78:1560-7. Epub 2012/04/21.

33. Hendriksz CJ, Pineda M, Fahey M, Walterfang M, Runz H, Stampfer M, Patterson MC, Torres JV, Kolb SA. The Niemann-Pick disease Type C suspicion index: development of a revised tool with improved predictive ability. J Inherit Metab Dis. 2014;37 Abstract P-372.

34. Sheth J, Mistri M, Sheth F, Shah R, Bavdekar A, Godbole K, Nanavaty N, Datar C, Kamate M, Oza N, Ankleshwaria C, Mehta S, Jackson M. Burden of lysosomal storage disorders in India: experience of 387 affected children from a single diagnostic facility. JIMD Reports. 2014;12:51-63. Epub 2013/07/16.

35. Corry PC. Consanguinity and prevalence patterns of inherited disease in the UK Pakistani community. Hum Heredity. 2014;77:207-16. Epub 2014/07/26.

36. Jaouad IC, Elalaoui SC, Sbiti A, Elkerh F, Belmahi L, Sefiani A. Consanguineous marriages in Morocco and the consequence for the incidence of autosomal recessive disorders. J Biosocial Sci. 2009;41:575-81. Epub 2009/05/13.

37. Tuncbilek E. Clinical outcomes of consanguineous marriages in Turkey. Turkish $\mathbf{J}$ Pediatr. 2001;43:277-9. Epub 2002/01/05.

38. Bauer P, Knoblich R, Bauer C, Finckh U, Hufen A, Kropp J, Braun S, KustermannKuhn B, Schmidt D, Harzer K, Rolfs A. NPC1: Complete genomic sequence, mutation analysis, and characterization of haplotypes. Hum Mutat. 2002;19:30-8. Epub 2001/12/26. 
39. Millat G, Chikh K, Naureckiene S, Sleat DE, Fensom AH, Higaki K, Elleder M, Lobel P, Vanier MT. Niemann-Pick disease type C: spectrum of HE1 mutations and genotype/phenotype correlations in the NPC2 group. Am J Hum Genet. 2001;69:101321. Epub 2001/09/22.

40. Fernandez-Valero EM, Ballart A, Iturriaga C, Lluch M, Macias J, Vanier MT, Pineda M, Coll MJ. Identification of 25 new mutations in 40 unrelated Spanish Niemann-Pick type C patients: genotype-phenotype correlations. Clin Genet. 2005;68:245-54. Epub 2005/08/16.

41. Cervera-Gaviria M, Alcantara-Ortigoza MA, Gonzalez-Del Angel A, Moyers-Perez P, Legorreta-Ramirez BG, Barrera-Carmona N, Cervera-Gaviria J. An uncommon inheritance pattern in Niemann-Pick disease type $\mathrm{C}$ : identification of probable paternal germline mosaicism in a Mexican family. BMC Neurol. 2016;16:147. Epub $2016 / 08 / 24$.

42. Imrie J, Heptinstall L, Knight S, Strong K. Observational cohort study of the natural history of Niemann-Pick disease type C in the UK: a 5-year update from the UK clinical database. BMC Neurol. 2015;15:257.

43. Moammar H, Cheriyan G, Mathew R, Al-Sannaa N. Incidence and patterns of inborn errors of metabolism in the Eastern Province of Saudi Arabia, 1983-2008. Ann Saudi Med. 2010;30:271-7. Epub 2010/07/14.

44. Al-Jasmi FA, Tawfig N, Berniah A, Ali BR, Taleb M, Hertecant JL, Bastaki F, Souid AK. Prevalence and Novel Mutations of Lysosomal Storage Disorders in United Arab Emirates : LSD in UAE. JIMD Reports. 2013;10:1-9. Epub 2013/02/23.

45. Elmonem MA, Mahmoud IG, Mehaney DA, Sharaf SA, Hassan SA, Orabi A, Salem F, Girgis MY, El-Badawy A, Abdelwahab M, Salah Z, Soliman NA, Hassan FA, Selim LA. Lysosomal Storage Disorders in Egyptian Children. Indian J Pediatr. 2016;83:80513. Epub 2016/02/03.

46. Akbayram S, Sari N, Akgun C, Dogan M, Tuncer O, Caksen H, Oner AF. The frequency of consanguineous marriage in eastern Turkey. Genet Counseling. 2009;20:207-14. Epub 2009/10/27.

47. Christopher R, Nalini A. Cerebral lipidoses in patients with progressive neurodegeneration: a study from south India. Commun Genet. 2002;5:186-91. Epub 2004/02/13. 
48. Bener A, Hussain R, Teebi AS. Consanguineous marriages and their effect on common diseases in the qatari population. Med Princ Pract. 2007:262-7.

49. Ben Halim N, Hsouna S, Lasram K, Rejeb I, Walha A, Talmoudi F, Messai H, Sabrine Ben Brick A, Ouragini H, Cherif W, Nagara M, Ben Rhouma F, Chouchene I, Ouechtati F, Bouyacoub Y, Ben Rekaya M, Messaoud O, Ben Ammar S, El Matri L, Tebib N, Ben Dridi MF, Mokni M, Amouri A, Kefi R, Abdelhak S. Differential impact of consanguineous marriages on autosomal recessive diseases in Tunisia. Am J Hum Biol. 2016;28:171-80. Epub 2015/07/17.

50. Millat G, Marcais C, Rafi MA, Yamamoto T, Morris JA, Pentchev PG, Ohno K, Wenger DA, Vanier MT. Niemann-Pick C1 disease: the I1061T substitution is a frequent mutant allele in patients of Western European descent and correlates with a classic juvenile phenotype. Am J Hum Genet. 1999;65:1321-9. Epub 1999/10/16.

51. Mavridou I, Cozar M, Douzgou S, Xaidara A, Lianou D, Vanier MT, Dimitriou E, Grinberg D, Vilageliu L, Michelakakis H. Niemann-Pick type C disease: a novel NPC1 mutation segregating in a Greek island. Clin Genet. 2014;85:543-7. Epub 2013/05/25.

52. Greer WL, Riddell DC, Gillan TL, Girouard GS, Sparrow SM, Byers DM, Dobson MJ, Neumann PE. The Nova Scotia (type D) form of Niemann-Pick disease is caused by a G3097-->T transversion in NPC1. Am J Hum Genet. 1998;63:52-4. Epub 1998/06/23.

53. Winsor EJ, Welch JP. Genetic and demographic aspects of Nova Scotia Niemann-Pick disease (type D). Am J Hum Genet. 1978;30:530-8. Epub 1978/09/01.

54. Alazami AM, Patel N, Shamseldin HE, Anazi S, Al-Dosari MS, Alzahrani F, Hijazi H, Alshammari M, Aldahmesh MA, Salih MA, Faqeih E, Alhashem A, Bashiri FA, AlOwain M, Kentab AY, Sogaty S, Al Tala S, Temsah MH, Tulbah M, Aljelaify RF, Alshahwan SA, Seidahmed MZ, Alhadid AA, Aldhalaan H, AlQallaf F, Kurdi W, Alfadhel M, Babay Z, Alsogheer M, Kaya N, Al-Hassnan ZN, Abdel-Salam GM, AlSannaa N, Al Mutairi F, El Khashab HY, Bohlega S, Jia X, Nguyen HC, Hammami R, Adly N, Mohamed JY, Abdulwahab F, Ibrahim N, Naim EA, Al-Younes B, Meyer BF, Hashem M, Shaheen R, Xiong Y, Abouelhoda M, Aldeeri AA, Monies DM, Alkuraya FS. Accelerating novel candidate gene discovery in neurogenetic disorders via wholeexome sequencing of prescreened multiplex consanguineous families. Cell Reports. 2015;10:148-61. Epub 2015/01/06. 
55. Mechtler TP, Metz TF, Muller HG, Ostermann K, Ratschmann R, De Jesus VR, Shushan B, Di Bussolo JM, Herman JL, Herkner KR, Kasper DC. Short-incubation mass spectrometry assay for lysosomal storage disorders in newborn and high-risk population screening. J Chromatogr B Analyt Technol Biomed Life Sci. 2012;908:9-17. Epub 2012/11/06.

56. Schicks J, Muller Vom Hagen J, Bauer P, Beck-Wodl S, Biskup S, Krageloh-Mann I, Schols L, Synofzik M. Niemann-Pick type $\mathrm{C}$ is frequent in adult ataxia with cognitive decline and vertical gaze palsy. Neurology. 2013;80:1169-70. Epub 2013/02/22.

57. Garver WS, Francis GA, Jelinek D, Shepherd G, Flynn J, Castro G, Walsh Vockley C, Coppock DL, Pettit KM, Heidenreich RA, Meaney FJ. The National Niemann-Pick C1 disease database: report of clinical features and health problems. Am J Med Genet A. 2007;143A:1204-11. Epub 2007/05/15.

58. Micheli F, Perandones C, Giugni J, Gonzalez-Aleman G, Raina G, Pellene L, Bruni D, Radrizzani M. Is progressive supranuclear palsy part of the phenotypic spectrum of NiemannPick disease type C? Neurology. 2013;80:P04.158.

59. Anheim M, Lagha-Boukbiza O, Fleury-Lesaunier MC, Valenti-Hirsch MP, Hirsch E, Gervais-Bernard H, Broussolle E, Thobois S, Vanier MT, Latour P, Tranchant C. Heterogeneity and frequency of movement disorders in juvenile and adult-onset Niemann-Pick C disease. J Neurol. 2014;261:174-9. Epub 2013/11/02.

60. Anheim M, Tranchant C, Koenig M. The autosomal recessive cerebellar ataxias. N Engl J Med. 2012;366:636-46. Epub 2012/02/18.

61. Sedel F, Saudubray JM, Roze E, Agid Y, Vidailhet M. Movement disorders and inborn errors of metabolism in adults: a diagnostic approach. J Inherit Metab Dis. 2008;31:308-18. Epub 2008/06/20.

62. Braga Neto P, Pedroso JL, Kuo SH, Marcondes Junior CF, Teive HA, Barsottini OG. Current concepts in the treatment of hereditary ataxias. Arq Neuropsiquiatr. 2016;74:244-52. Epub 2016/04/07.

63. Koens LH, Kuiper A, Coenen MA, Elting JW, de Vries JJ, Engelen M, Koelman JH, van Spronsen FJ, Spikman JM, de Koning TJ, Tijssen MA. Ataxia, dystonia and myoclonus in adult patients with Niemann-Pick type C. Orphanet J Rare Dis. 2016;11:121. Epub 2016/09/02. 
64. Mallaret M, Renaud M, Redin C, Drouot N, Muller J, Severac F, Mandel JL, Hamza W, Benhassine T, Ali-Pacha L, Tazir M, Durr A, Monin ML, Mignot C, Charles P, Van Maldergem L, Chamard L, Thauvin-Robinet C, Laugel V, Burglen L, Calvas P, Fleury MC, Tranchant C, Anheim M, Koenig M. Validation of a clinical practice-based algorithm for the diagnosis of autosomal recessive cerebellar ataxias based on NGS identified cases. J Neurol. 2016;263:1314-22. Epub 2016/05/05.

65. Anheim M, Fleury M, Monga B, Laugel V, Chaigne D, Rodier G, Ginglinger E, Boulay C, Courtois S, Drouot N, Fritsch M, Delaunoy JP, Stoppa-Lyonnet D, Tranchant C, Koenig M. Epidemiological, clinical, paraclinical and molecular study of a cohort of 102 patients affected with autosomal recessive progressive cerebellar ataxia from Alsace, Eastern France: implications for clinical management. Neurogenetics. 2010;11:1-12. Epub 2009/05/15.

66. Tripathi M, Tang CC, Feigin A, De Lucia I, Nazem A, Dhawan V, Eidelberg D. Automated differential diagnosis of early parkinsonism using metabolic brain networks: a validation study. J Nucl Med. 2016;57:60-6. Epub 2015/10/10.

67. Mancuso M, Orsucci D, Siciliano G, Bonuccelli U. The genetics of ataxia: through the labyrinth of the Minotaur, looking for Ariadne's thread. J Neurol. 2014;261 Suppl 2:S528-41. Epub 2014/08/26.

68. Harmuth F, Synofzik M, Stampfer M, Müller vom Hagen J, Sturm M, Schöls L, Bauer P. NPC1/2 mutations are significantly enriched in a cohort of unexplained early onset ataxia [abstract P-ClinG-097]. Medizinische Genetik. 2016:153.

69. Sevin M, Lesca G, Baumann N, Millat G, Lyon-Caen O, Vanier MT, Sedel F. The adult form of Niemann-Pick disease type C. Brain. 2007;130:120-33. Epub 2006/09/28.

70. de Koning TJ, Tijssen MA. Movement disorders in 2014. Genetic advances spark a revolution in dystonia phenotyping. Nat Rev Neurol. 2015;11:78-9. Epub 2015/01/07.

71. Hubsch C, Roze E, Popa T, Russo M, Balachandran A, Pradeep S, Mueller F, Brochard V, Quartarone A, Degos B, Vidailhet M, Kishore A, Meunier S. Defective cerebellar control of cortical plasticity in writer's cramp. Brain. 2013;136:2050-62. Epub $2013 / 06 / 27$.

72. Bonnot O, Herrera PM, Tordjman S, Walterfang M. Secondary psychosis induced by metabolic disorders. Front Neurosci. 2015;9:177. Epub 2015/06/16. 
73. Albanese A, Bhatia K, Bressman SB, Delong MR, Fahn S, Fung VS, Hallett M, Jankovic J, Jinnah HA, Klein C, Lang AE, Mink JW, Teller JK. Phenomenology and classification of dystonia: a consensus update. Mov Disord. 2013;28:863-73. Epub 2013/05/08.

74. Bonnot O, Gama CS, Mengel E, Pineda M, Vanier MT, Watson L, Watissée M, Schwierin B, Patterson MC. Psychiatric and neurological symptoms in patients with Niemann-Pick disease type C (NP-C): findings from the International NPC Registry. J Inherit Metab Dis. 2016;39(Suppl 1):S62-3.

75. J. Crespia J, Bråthena G, Quist-Paulsenb P, Pagonabarragad J, Roig-Arnalld C. Facial dystonia with facial grimacing and vertical gaze palsy with "round the houses" sign in a 29-year-old woman. Neuro-ophthalmology. 2016;40:37-41.

76. Bauer P, Balding DJ, Klünemann HH, Linden DE, Ory DS, Pineda M, Priller J, Sedel F, Muller A, Chadha-Boreham H, Welford RW, Strasser DS, Patterson MC. Genetic screening for Niemann-Pick disease type $\mathrm{C}$ in adults with neurological and psychiatric symptoms: findings from the ZOOM study. Hum Mol Genet. 2013;22:4349-56. Epub 2013/06/19.

77. Nunn K, Williams K, Ouvrier R. The Australian childhood dementia study. Eur Child Adolesc Psychiatry. 2002;11:63-70. Epub 2002/05/30.

78. Cupidi C, Frangipane F, Gallo M, Clodomiro A, Colao R, Bernardi L, Anfossi M, Conidi ME, Vasso F, Curcio SA, Mirabelli M, Smirne N, Torchia G, Muraca MG, Puccio G, Di Lorenzo R, Zampieri S, Romanello M, Dardis A, Maletta RG, Bruni AC. Role of Niemann-Pick type C disease mutations in dementia. J Alzheimers Dis. 2016;55:1249-59. Epub 2016/10/30.

79. Saito Y, Suzuki K, Nanba E, Yamamoto T, Ohno K, Murayama S. Niemann-Pick type C disease: accelerated neurofibrillary tangle formation and amyloid beta deposition associated with apolipoprotein E epsilon 4 homozygosity. Ann Neurol. 2002;52:351-5. Epub 2002/09/03.

80. Saito Y, Suzuki K, Hulette CM, Murayama S. Aberrant phosphorylation of alphasynuclein in human Niemann-Pick type C1 disease. J Neuropathol Exp Neurol. 2004;63:323-8. Epub 2004/04/22.

81. Love S, Bridges LR, Case CP. Neurofibrillary tangles in Niemann-Pick disease type C. Brain. 1995;118 ( Pt 1):119-29. Epub 1995/02/01. 
82. Contreras PS, Gonzalez-Zuniga M, Gonzalez-Hodar L, Yanez MJ, Dulcey A, Marugan J, Seto E, Alvarez AR, Zanlungo S. Neuronal gene repression in Niemann-Pick type C models is mediated by the c-Abl/HDAC2 signaling pathway. Biochim Biophys Acta. 2016;1859:269-79. Epub 2015/11/26.

83. Yanez MJ, Belbin O, Estrada LD, Leal N, Contreras PS, Lleo A, Burgos PV, Zanlungo S, Alvarez AR. c-Abl links APP-BACE1 interaction promoting APP amyloidogenic processing in Niemann-Pick type C disease. Biochim Biophys Acta. 2016;1862:21582167. Epub 2016/08/28.

84. Reddy JV, Ganley IG, Pfeffer SR. Clues to neuro-degeneration in Niemann-Pick type C disease from global gene expression profiling. PLoS ONE. 2006;1:e19. Epub $2006 / 12 / 22$.

85. Mattsson N, Zetterberg H, Bianconi S, Yanjanin NM, Fu R, Mansson JE, Porter FD, Blennow K. Gamma-secretase-dependent amyloid-beta is increased in Niemann-Pick type C: a cross-sectional study. Neurology. 2011;76:366-72. Epub 2011/01/06.

86. Fu R, Yanjanin NM, Elrick MJ, Ware C, Lieberman AP, Porter FD. Apolipoprotein E genotype and neurological disease onset in Niemann-Pick disease, type C1. Am J Med Genet A. 2012;158A:2775-80. Epub 2012/10/02.

87. Chua CC, Lim ML, Wong BS. Altered apolipoprotein E glycosylation is associated with Abeta(42) accumulation in an animal model of Niemann-Pick Type C disease. $\mathbf{J}$ Neurochem. 2010;112:1619-26. Epub 2010/01/15.

88. Imrie J, Vijayaraghaven S, Whitehouse C, Harris S, Heptinstall L, Church H, Cooper A, Besley GT, Wraith JE. Niemann-Pick disease type C in adults. J Inherit Metab Dis. 2002;25:491-500. Epub 2003/01/31.

89. Klarner B, Klünemann HH, Lurding R, Aslanidis C, Rupprecht R. Neuropsychological profile of adult patients with Niemann-Pick C1 (NPC1) mutations. J Inherit Metab Dis. 2007;30:60-7. Epub 2006/12/13.

90. Abela L, Plecko B, Palla A, Burda P, Nuoffer JM, Ballhausen D, Rohrbach M. Early co-occurrence of a neurologic-psychiatric disease pattern in Niemann-Pick type C disease: a retrospective Swiss cohort study. Orphanet J Rare Dis. 2014;9:176. Epub $2014 / 11 / 27$.

91. Webber D, Klünemann HH. Psychiatric manifestations of Niemann-Pick disease. J Inherit Metab Dis. 2011;4:25-31. 
92. Staretz-Chacham O, Choi JH, Wakabayashi K, Lopez G, Sidransky E. Psychiatric and behavioral manifestations of lysosomal storage disorders. Am J Med Genet B Neuropsychiatr Genet. 2010;153B:1253-65. Epub 2010/09/28.

93. Josephs KA, Van Gerpen MW, Van Gerpen JA. Adult onset Niemann-Pick disease type C presenting with psychosis. J Neurol Neurosurg Psychiatry. 2003;74:528-9. Epub 2003/03/18.

94. Stampfer M, Theiss S, Amraoui Y, Jiang X, Keller S, Ory DS, Mengel E, Fischer C, Runz H. Niemann-Pick disease type $\mathrm{C}$ clinical database: cognitive and coordination deficits are early disease indicators. Orphanet J Rare Dis. 2013;8:35. Epub 2013/02/26.

95. Nia S. Psychiatric signs and symptoms in treatable inborn errors of metabolism. J Neurol. 2014;261 Suppl 2:S559-68. Epub 2014/08/26.

96. Hulette CM, Earl NL, Anthony DC, Crain BJ. Adult onset Niemann-Pick disease type C presenting with dementia and absent organomegaly. Clin Neuropathol. 1992;11:293-7. Epub 1992/11/01.

97. Hendriksz CJ, Pineda M, Fahey M, Walterfang M, Runz H, Stampfer M, Patterson MC, Torres JV, Kolb SA. Improving NP-C screening: identification of seven key discriminatory signs and symptoms. J Inherit Metab Dis. 2014;37 Abstract P-371.

98. Chow TW, Miller BL, Boone K, Mishkin F, Cummings JL. Frontotemporal dementia classification and neuropsychiatry. Neurologist. 2002;8:263-9. Epub 2003/06/14.

99. Knopman DS, Petersen RC, Edland SD, Cha RH, Rocca WA. The incidence of frontotemporal lobar degeneration in Rochester, Minnesota, 1990 through 1994. Neurology. 2004;62:506-8. Epub 2004/02/12.

100. Laforce R, Jr. Behavioral and language variants of frontotemporal dementia: a review of key symptoms. Clin Neurol Neurosurg. 2013;115:2405-10. Epub 2014/01/22.

101. McKhann GM, Albert MS, Grossman M, Miller B, Dickson D, Trojanowski JQ, Work Group on Frontotemporal D, Pick's D. Clinical and pathological diagnosis of frontotemporal dementia: report of the Work Group on Frontotemporal Dementia and Pick's Disease. Arch Neurol. 2001;58:1803-9. Epub 2001/11/16.

102. Walterfang M, Fietz M, Fahey M, Sullivan D, Leane P, Lubman DI, Velakoulis D. The neuropsychiatry of Niemann-Pick type C disease in adulthood. J Neuropsychiatry Clin Neurosci. 2006;18:158-70. Epub 2006/05/25. 
103. Maubert A, Hanon C, Metton JP. [Adult onset Niemann-Pick type C disease and psychosis: literature review]. L'Encephale. 2013;39:315-9. Epub 2013/08/10.

104. Bonnot O. Niemann-Pick disease type $\mathrm{C}$ - example of an inborn error of metabolism producing psychiatric manifestations. Eur Psychiatr Rev. 2011;4:84-8.

105. Gustafson L, Brun A, Passant U. Frontal lobe degeneration of non-Alzheimer type. Bailliere's Clin Neurol. 1992;1:559-82. Epub 1992/11/01.

106. Velakoulis D, Walterfang M, Mocellin R, Pantelis C, McLean C. Frontotemporal dementia presenting as schizophrenia-like psychosis in young people: clinicopathological series and review of cases. Br J Psychiatry. 2009;194:298-305. Epub 2009/04/02.

107. Sjogren M, Gustafson L, Wikkelso C, Wallin A. Frontotemporal dementia can be distinguished from Alzheimer's disease and subcortical white matter dementia by an anterior-to-posterior rCBF-SPET ratio. Dement Geriatr Cogn Disord. 2000;11:275-85. Epub 2000/08/15.

108. Klünemann HH, Santosh PJ, Sedel F. Treatable metabolic psychoses that go undetected: what Niemann-Pick type $\mathrm{C}$ can teach us. Int J Psychiatry Clin Pract. 2012;16:162-9. Epub 2012/07/04.

109. Shulman LM, David NJ, Weiner WJ. Psychosis as the initial manifestation of adultonset Niemann-Pick disease type C. Neurology. 1995;45:1739-43. Epub 1995/09/01.

110. Stone J, Griffiths TD, Rastogi S, Perry RH, Cleland PG. Non-Picks frontotemporal dementia imitating schizophrenia in a 22-year-old man. J Neurol. 2003;250:369-70. Epub 2003/05/17.

111. Momeni P, Wickremaratchi MM, Bell J, Arnold R, Beer R, Hardy J, Revesz T, Neal JW, Morris HR. Familial early onset frontotemporal dementia caused by a novel S356T MAPT mutation, initially diagnosed as schizophrenia. Clin Neurol Neurosurg. 2010;112:917-20. Epub 2010/08/17.

112. Gourzis P, Skokou M, Polychronopoulos P, Soubasi E, Triantaphyllidou IE, Aravidis C, Sarela AI, Kosmaidou Z. Frontotemporal dementia, manifested as schizophrenia, with decreased heterochromatin on chromosome 1. Case Rep Psychiatry. 2012;2012:937518. Epub 2012/10/20.

113. Cooper JJ, Ovsiew F. The relationship between schizophrenia and frontotemporal dementia. J Geriatr Psychiatry Neurol. 2013;26:131-7. Epub 2013/06/05. 
114. Goldman JS, Farmer JM, Wood EM, Johnson JK, Boxer A, Neuhaus J, Lomen-Hoerth C, Wilhelmsen KC, Lee VM, Grossman M, Miller BL. Comparison of family histories in FTLD subtypes and related tauopathies. Neurology. 2005;65:1817-9. Epub 2005/12/14.

115. Le Ber I, Camuzat A, Guillot-Noel L, Hannequin D, Lacomblez L, Golfier V, Puel M, Martinaud O, Deramecourt V, Rivaud-Pechoux S, Millecamps S, Vercelletto M, Couratier P, Sellal F, Pasquier F, Salachas F, Thomas-Anterion C, Didic M, Pariente J, Seilhean D, Ruberg M, Wargon I, Blanc F, Camu W, Michel BF, Berger E, Sauvee M, Thauvin-Robinet C, Mondon K, Tournier-Lasserve E, Goizet C, Fleury M, Viennet G, Verpillat P, Meininger V, Duyckaerts C, Dubois B, Brice A. C9ORF72 repeat expansions in the frontotemporal dementias spectrum of diseases: a flow-chart for genetic testing. J Alzheimers Dis. 2013;34:485-99. Epub 2012/12/21.

116. Devenney E, Foxe D, Dobson-Stone C, Kwok JB, Kiernan MC, Hodges JR. Clinical heterogeneity of the C9orf72 genetic mutation in frontotemporal dementia. Neurocase. 2015;21:535-41. Epub 2014/08/21.

117. Wood H. A hexanucleotide repeat expansion in C9ORF72 links amyotrophic lateral sclerosis and frontotemporal dementia. Nat Rev Neurol. 2011;7:595. Epub 2011/10/20.

118. Mahoney CJ, Beck J, Rohrer JD, Lashley T, Mok K, Shakespeare T, Yeatman T, Warrington EK, Schott JM, Fox NC, Rossor MN, Hardy J, Collinge J, Revesz T, Mead S, Warren JD. Frontotemporal dementia with the C9ORF72 hexanucleotide repeat expansion: clinical, neuroanatomical and neuropathological features. Brain. 2012;135:736-50. Epub 2012/03/01.

119. Baker M, Mackenzie IR, Pickering-Brown SM, Gass J, Rademakers R, Lindholm C, Snowden J, Adamson J, Sadovnick AD, Rollinson S, Cannon A, Dwosh E, Neary D, Melquist S, Richardson A, Dickson D, Berger Z, Eriksen J, Robinson T, Zehr C, Dickey CA, Crook R, McGowan E, Mann D, Boeve B, Feldman H, Hutton M. Mutations in progranulin cause tau-negative frontotemporal dementia linked to chromosome 17. Nature. 2006;442:916-9. Epub 2006/07/25.

120. Ludolph AC, Kassubek J, Landwehrmeyer BG, Mandelkow E, Mandelkow EM, Burn DJ, Caparros-Lefebvre D, Frey KA, de Yebenes JG, Gasser T, Heutink P, Hoglinger G, Jamrozik Z, Jellinger KA, Kazantsev A, Kretzschmar H, Lang AE, Litvan I, Lucas JJ, McGeer PL, Melquist S, Oertel W, Otto M, Paviour D, Reum T, Saint-Raymond A, 
Steele JC, Tolnay M, Tumani H, van Swieten JC, Vanier MT, Vonsattel JP, Wagner S, Wszolek ZK, Reisensburg Working Group for Tauopathies With P. Tauopathies with parkinsonism: clinical spectrum, neuropathologic basis, biological markers, and treatment options. Eur J Neurol. 2009;16:297-309. Epub 2009/04/15.

121. Ghetti B, Oblak AL, Boeve BF, Johnson KA, Dickerson BC, Goedert M. Invited review: Frontotemporal dementia caused by microtubule-associated protein tau gene (MAPT) mutations: a chameleon for neuropathology and neuroimaging. Neuropathol Appl Neurobiol. 2015;41:24-46. Epub 2015/01/06.

122. Hutton M, Lendon CL, Rizzu P, Baker M, Froelich S, Houlden H, Pickering-Brown S, Chakraverty S, Isaacs A, Grover A, Hackett J, Adamson J, Lincoln S, Dickson D, Davies P, Petersen RC, Stevens M, de Graaff E, Wauters E, van Baren J, Hillebrand M, Joosse M, Kwon JM, Nowotny P, Che LK, Norton J, Morris JC, Reed LA, Trojanowski J, Basun H, Lannfelt L, Neystat M, Fahn S, Dark F, Tannenberg T, Dodd PR, Hayward N, Kwok JB, Schofield PR, Andreadis A, Snowden J, Craufurd D, Neary D, Owen F, Oostra BA, Hardy J, Goate A, van Swieten J, Mann D, Lynch T, Heutink P. Association of missense and 5'-splice-site mutations in tau with the inherited dementia FTDP-17. Nature. 1998;393:702-5. Epub 1998/06/26.

123. Goedert M, Spillantini MG. Pathogenesis of the tauopathies. J Mol Neurosci. 2011;45:425-31. Epub 2011/07/26.

124. Arvanitakis Z. Update on frontotemporal dementia. Neurologist. 2010;16:16-22. Epub 2010/01/13.

125. Badiola N, Suarez-Calvet M, Lleo A. Tau phosphorylation and aggregation as a therapeutic target in tauopathies. CNS Neurol Disord Drug Targets. 2010;9:727-40. Epub 2010/10/15.

126. Baizabal-Carvallo JF, Jankovic J. Parkinsonism, movement disorders and genetics in frontotemporal dementia. Nat Rev Neurol. 2016;12:175-85.

127. Coleman RJ, Robb SA, Lake BD, Brett EM, Harding AE. The diverse neurological features of Niemann-Pick disease type C: a report of two cases. Mov Disord. 1988;3:295-9. Epub 1988/01/01.

128. Nalls MA, Pankratz N, Lill CM, Do CB, Hernandez DG, Saad M, DeStefano AL, Kara E, Bras J, Sharma M, Schulte C, Keller MF, Arepalli S, Letson C, Edsall C, Stefansson H, Liu X, Pliner H, Lee JH, Cheng R, International Parkinson's Disease Genomics C, 
Parkinson's Study Group Parkinson's Research: The Organized GI, andMe, GenePd, NeuroGenetics Research C, Hussman Institute of Human G, Ashkenazi Jewish Dataset I, Cohorts for H, Aging Research in Genetic E, North American Brain Expression C, United Kingdom Brain Expression C, Greek Parkinson's Disease C, Alzheimer Genetic Analysis G, Ikram MA, Ioannidis JP, Hadjigeorgiou GM, Bis JC, Martinez M, Perlmutter JS, Goate A, Marder K, Fiske B, Sutherland M, Xiromerisiou G, Myers RH, Clark LN, Stefansson K, Hardy JA, Heutink P, Chen H, Wood NW, Houlden H, Payami H, Brice A, Scott WK, Gasser T, Bertram L, Eriksson N, Foroud T, Singleton AB. Large-scale meta-analysis of genome-wide association data identifies six new risk loci for Parkinson's disease. Nat Genet. 2014;46:989-93. Epub 2014/07/30.

129. Dehay B, Martinez-Vicente M, Caldwell GA, Caldwell KA, Yue Z, Cookson MR, Klein C, Vila M, Bezard E. Lysosomal impairment in Parkinson's disease. Mov Disord. 2013;28:725-32. Epub 2013/04/13.

130. Gan-Or Z, Dion PA, Rouleau GA. Genetic perspective on the role of the autophagylysosome pathway in Parkinson disease. Autophagy. 2016;11:1443-57. Epub $2015 / 07 / 25$.

131. Alcalay RN, Levy OA, Waters CC, Fahn S, Ford B, Kuo SH, Mazzoni P, Pauciulo MW, Nichols WC, Gan-Or Z, Rouleau GA, Chung WK, Wolf P, Oliva P, Keutzer J, Marder K, Zhang X. Glucocerebrosidase activity in Parkinson's disease with and without GBA mutations. Brain. 2015;138:2648-58. Epub 2015/06/29.

132. Dagan E, Schlesinger I, Ayoub M, Mory A, Nassar M, Kurolap A, Peretz-Aharon J, Gershoni-Baruch R. The contribution of Niemann-Pick SMPD1 mutations to Parkinson disease in Ashkenazi Jews. Parkinsonism Relat Disord. 2015;21:1067-71. Epub $2015 / 07 / 15$.

133. Sidransky E, Nalls MA, Aasly JO, Aharon-Peretz J, Annesi G, Barbosa ER, Bar-Shira A, Berg D, Bras J, Brice A, Chen CM, Clark LN, Condroyer C, De Marco EV, Durr A, Eblan MJ, Fahn S, Farrer MJ, Fung HC, Gan-Or Z, Gasser T, Gershoni-Baruch R, Giladi N, Griffith A, Gurevich T, Januario C, Kropp P, Lang AE, Lee-Chen GJ, Lesage S, Marder K, Mata IF, Mirelman A, Mitsui J, Mizuta I, Nicoletti G, Oliveira C, Ottman R, Orr-Urtreger A, Pereira LV, Quattrone A, Rogaeva E, Rolfs A, Rosenbaum H, Rozenberg R, Samii A, Samaddar T, Schulte C, Sharma M, Singleton A, Spitz M, Tan EK, Tayebi N, Toda T, Troiano AR, Tsuji S, Wittstock M, Wolfsberg TG, Wu YR, 
Zabetian CP, Zhao Y, Ziegler SG. Multicenter analysis of glucocerebrosidase mutations in Parkinson's disease. N Engl J Med. 2009;361:1651-61. Epub 2009/10/23.

134. Gan-Or Z, Giladi N, Rozovski U, Shifrin C, Rosner S, Gurevich T, Bar-Shira A, OrrUrtreger A. Genotype-phenotype correlations between GBA mutations and Parkinson disease risk and onset. Neurology. 2008;70:2277-83. Epub 2008/04/25.

135. Kim J, Sidransky E, Lopez G. Understanding and managing parkinsonism in patients with glucocerebrosidase mutations. Exp Opin Orphan Drugs. 2015;3:549-62.

136. Gan-Or Z, Ozelius LJ, Bar-Shira A, Saunders-Pullman R, Mirelman A, Kornreich R, Gana-Weisz M, Raymond D, Rozenkrantz L, Deik A, Gurevich T, Gross SJ, SchreiberAgus N, Giladi N, Bressman SB, Orr-Urtreger A. The p.L302P mutation in the lysosomal enzyme gene SMPD1 is a risk factor for Parkinson disease. Neurology. 2013;80:1606-10. Epub 2013/03/29.

137. Liu JP, Tang Y, Zhou S, Toh BH, McLean C, Li H. Cholesterol involvement in the pathogenesis of neurodegenerative diseases. Mol Cell Neurosci. 2010;43:33-42. Epub 2009/08/08.

138. Chiba Y, Komori H, Takei S, Hasegawa-Ishii S, Kawamura N, Adachi K, Nanba E, Hosokawa M, Enokido Y, Kouchi Z, Yoshida F, Shimada A. Niemann-Pick disease type $\mathrm{C} 1$ predominantly involving the frontotemporal region, with cortical and brainstem Lewy bodies: an autopsy case. Neuropathology. 2014;34:49-57. Epub 2013/05/29.

139. Deng H, Xiu X, Jankovic J. Genetic convergence of Parkinson's disease and lysosomal storage disorders. Mol Neurobiol. 2015;51:1554-68. Epub 2014/08/07.

140. Klünemann HH, Nutt JG, Davis MY, Bird TD. Parkinsonism syndrome in heterozygotes for Niemann-Pick C1. J Neurol Sci. 2013;335:219-20. Epub 2013/09/17.

141. Josephs KA, Matsumoto JY, Lindor NM. Heterozygous Niemann-Pick disease type C presenting with tremor. Neurology. 2004;63:2189-90. Epub 2004/12/15.

142. Houghton DJ, Litvan I. Unraveling progressive supranuclear palsy: from the bedside back to the bench. Parkinsonism Relat Disord. 2007;13 Suppl 3:S341-6. Epub 2008/11/19.

143. Duvoisin RC. Differential diagnosis of PSP. J Neural Transm Suppl. 1994;42:51-67. Epub 1994/01/01. 
144. Stamelou M, Hoeglinger GU. Atypical parkinsonism: an update. Curr Opin Neurol. 2013;26:401-5. Epub 2013/07/03.

145. Eggink H, Brandsma R, van der Hoeven JH, Lange F, de Koning TJ, Tijssen MA. Teaching Video NeuroImages: The "round the houses" sign as a clinical clue for Niemann-Pick disease type C. Neurology. 2016;86:e202. Epub 2016/05/11.

146. Godeiro-Junior C, Inaoka RJ, Barbosa MR, Silva MR, Aguiar Pde C, Barsottini O. Mutations in NPC1 in two Brazilian patients with Niemann-Pick disease type C and progressive supranuclear palsy-like presentation. Mov Disord. 2006;21:2270-2. Epub 2006/10/18.

147. Lengyel D, Weissert M, Schmid L, Gottlob I. [Eye movement abnormalities as a sign for the diagnosis in Niemann-Pick disease type C]. Klinische Monatsblatter fur Augenheilkunde. 1999;214:50-2. Epub 1999/04/13.

148. Salsano E, Umeh C, Rufa A, Pareyson D, Zee DS. Vertical supranuclear gaze palsy in Niemann-Pick type C disease. Neurol Sci. 2012;33:1225-32. Epub 2012/07/20.

149. Strupp M, Kremmyda O, Adamczyk C, Bottcher N, Muth C, Yip CW, Bremova T. Central ocular motor disorders, including gaze palsy and nystagmus. J Neurol. 2014;261 Suppl 2:S542-58. Epub 2014/08/26.

150. Walterfang M, Macfarlane MD, Looi JC, Abel L, Bowman E, Fahey MC, Desmond P, Velakoulis D. Pontine-to-midbrain ratio indexes ocular-motor function and illness stage in adult Niemann-Pick disease type C. Eur J Neurol. 2012;19:462-7. Epub 2012/02/15.

151. Abel LA, Walterfang M, Fietz M, Bowman EA, Velakoulis D. Saccades in adult Niemann-Pick disease type $\mathrm{C}$ reflect frontal, brainstem, and biochemical deficits. Neurology. 2009;72:1083-6. Epub 2009/03/25.

152. Solomon D, Winkelman AC, Zee DS, Gray L, Buttner-Ennever J. Niemann-Pick type C disease in two affected sisters: ocular motor recordings and brain-stem neuropathology. Ann N Y Acad Sci. 2005;1039:436-45. Epub 2005/04/14.

153. Abel LA, Walterfang M, Stainer MJ, Bowman EA, Velakoulis D. Longitudinal assessment of reflexive and volitional saccades in Niemann-Pick Type $\mathrm{C}$ disease during treatment with miglustat. Orphanet J Rare Dis. 2015;10:160. Epub 2015/12/23.

154. Chio A, Borghero G, Restagno G, Mora G, Drepper C, Traynor BJ, Sendtner M, Brunetti M, Ossola I, Calvo A, Pugliatti M, Sotgiu MA, Murru MR, Marrosu MG, Marrosu F, Marinou K, Mandrioli J, Sola P, Caponnetto C, Mancardi G, Mandich P, La 
Bella V, Spataro R, Conte A, Monsurro MR, Tedeschi G, Pisano F, Bartolomei I, Salvi F, Lauria Pinter G, Simone I, Logroscino G, Gambardella A, Quattrone A, Lunetta C, Volanti P, Zollino M, Penco S, Battistini S, consortium I, Renton AE, Majounie E, Abramzon Y, Conforti FL, Giannini F, Corbo M, Sabatelli M. Clinical characteristics of patients with familial amyotrophic lateral sclerosis carrying the pathogenic GGGGCC hexanucleotide repeat expansion of C9ORF72. Brain. 2012;135:784-93. Epub 2012/03/01.

155. Dickson DW, Kouri N, Murray ME, Josephs KA. Neuropathology of frontotemporal lobar degeneration-tau (FTLD-tau). J Molec Neurosci. 2011;45:384-9. Epub 2011/07/02.

156. Dickson DW, Ahmed Z, Algom AA, Tsuboi Y, Josephs KA. Neuropathology of variants of progressive supranuclear palsy. Curr Opin Neurol. 2010;23:394-400. Epub 2010/07/09.

157. Höglinger G, Stamelou M, Kurz C, Josephs K, Lang A, Mollenhauer B, Müller U, Nilsson C, Whitwell J, Arzberger T, Gelpi E, Giese A, Irwin D, Meissner W, Pantelyat A, van Swieten J, Troakes C, Antonini A, Bhatia K, Bordelon Y, Corvol JC, Colosimo C, Dickson DW, Dodel R, Grossman M, Kassubek J, Krismer F, Levin J, Lorenzl S, Morris H, Nestor P, Oertel WH, Rabinovici G, Rowe J, Schellenberg G, T. vE, Wenning GK, J-T. Y, Boxer A, L.I. G, Litvan I. MDS-clinical diagnostic criteria for progressive supranuclear palsy (PSP). Presented at the 20th International Conference on Parkinson's Disease and Movement Disorders; 2016 [Abstract SG 35]. Available at: http://www.mdscongress2016.org/Congress-2016-Files/PDFs/LBASGGPTBooklet.pdf (accessed 31 Jan 2017).

158. Averbuch-Heller L, Paulson GW, Daroff RB, Leigh RJ. Whipple's disease mimicking progressive supranuclear palsy: the diagnostic value of eye movement recording. $\mathbf{J}$ Neurol Neurosurg Psychiatry. 1999;66:532-5. Epub 1999/04/14.

159. Marx S, Respondek G, Stamelou M, Dowiasch S, Stoll J, Bremmer F, Oertel WH, Hoglinger GU, Einhauser W. Validation of mobile eye-tracking as novel and efficient means for differentiating progressive supranuclear palsy from Parkinson's disease. Front Behav Neurosci. 2012;6:88. Epub 2012/12/19.

160. Borroni B, Malinverno M, Gardoni F, Alberici A, Parnetti L, Premi E, Bonuccelli U, Grassi M, Perani D, Calabresi P, Di Luca M, Padovani A. Tau forms in CSF as a 
reliable biomarker for progressive supranuclear palsy. Neurology. 2008;71:1796-803. Epub 2008/10/31.

161. Borroni B, Gardoni F, Parnetti L, Magno L, Malinverno M, Saggese E, Calabresi P, Spillantini MG, Padovani A, Di Luca M. Pattern of Tau forms in CSF is altered in progressive supranuclear palsy. Neurobiol Aging. 2009;30:34-40. Epub 2007/08/22.

162. Bonnot O, Klünemann HH, Sedel F, Tordjman S, Cohen D, Walterfang M. Diagnostic and treatment implications of psychosis secondary to treatable metabolic disorders in adults: a systematic review. Orphanet J Rare Dis. 2014;9:65. Epub 2014/04/30.

163. Sedel F, Baumann N, Turpin JC, Lyon-Caen O, Saudubray JM, Cohen D. Psychiatric manifestations revealing inborn errors of metabolism in adolescents and adults. J Inherit Metab Dis. 2007;30:631-41. Epub 2007/08/19.

164. Walterfang M, Fietz M, Abel L, Bowman E, Mocellin R, Velakoulis D. Gender dimorphism in siblings with schizophrenia-like psychosis due to Niemann-Pick disease type C. J Inherit Metab Dis. 2009;32 Suppl 1:S221-6. Epub 2009/07/18.

165. Kulhanek J, Albrecht J, Honzik T, Magner M. [Psychiatric manifestation of inborn errors of metabolism]. Ces a Slav Psychiat. 2015;111:295-305.

166. Atsuta N, Watanabe H, Ito M, Tanaka F, Tamakoshi A, Nakano I, Aoki M, Tsuji S, Yuasa T, Takano H, Hayashi H, Kuzuhara S, Sobue G, Research Committee on the Neurodegenerative Diseases of J. Age at onset influences on wide-ranged clinical features of sporadic amyotrophic lateral sclerosis. J Neurol Sci. 2009;276:163-9. Epub 2008/10/31.

167. Murray ME, Kouri N, Lin WL, Jack CR, Jr., Dickson DW, Vemuri P. Clinicopathologic assessment and imaging of tauopathies in neurodegenerative dementias. Alzheimers Res Ther. 2014;6:1. Epub 2014/01/03.

168. Diagnosis ETFo, Management of Amyotrophic Lateral S, Andersen PM, Abrahams S, Borasio GD, de Carvalho M, Chio A, Van Damme P, Hardiman O, Kollewe K, Morrison KE, Petri S, Pradat PF, Silani V, Tomik B, Wasner M, Weber M. EFNS guidelines on the clinical management of amyotrophic lateral sclerosis (MALS)-revised report of an EFNS task force. Eur J Neurol. 2012;19:360-75. Epub 2011/09/15.

169. Katsumata R, Ishigaki S, Katsuno M, Kawai K, Sone J, Huang Z, Adachi H, Tanaka F, Urano F, Sobue G. c-Abl inhibition delays motor neuron degeneration in the G93A 
mouse, an animal model of amyotrophic lateral sclerosis. PLoS One. 2012;7:e46185. Epub 2012/10/11.

170. Marin B, Beghi E, Vial C, Bernard E, Lautrette G, Clavelou P, Guy N, Lemasson G, Debruxelles S, Cintas P, Antoine JC, Camdessanche JP, Logroscino G, Preux PM, Couratier P, consortium E. Evaluation of the application of the European guidelines for the diagnosis and clinical care of amyotrophic lateral sclerosis (ALS) patients in six French ALS centres. Eur J Neurol. 2016;23:787-95. Epub 2016/02/03.

171. Andersen PM, Abrahams S, Borasio GD, de Carvalho M, Chio A, Van Damme P, Hardiman O, Kollewe K, Morrison KE, Petri S, Pradat PF, Silani V, Tomik B, Wasner M, Weber M, EFNS Task Force on Diagnosis Management of Amyotrophic Lateral, Sclerosis. EFNS guidelines on the clinical management of amyotrophic lateral sclerosis (MALS)--revised report of an EFNS task force. Eur J Neurol. 2012;19:360-75. Epub 2011/09/15.

172. Okita T, Nodera H, Shibuta Y, Nodera A, Asanuma K, Shimatani Y, Sato K, Izumi Y, Kaji R. Can Awaji ALS criteria provide earlier diagnosis than the revised El Escorial criteria? J Neurol Sci. 2011;302:29-32. Epub 2011/01/11.

173. Iodice R, Dubbioso R, Topa A, Ruggiero L, Pisciotta C, Esposito M, Tozza S, Santoro L, Manganelli F. Electrophysiological characterization of adult-onset Niemann-Pick type C disease. J Neurol Sci. 2015;348:262-5. Epub 2014/12/30.

174. Kingwell E, Marriott JJ, Jette N, Pringsheim T, Makhani N, Morrow SA, Fisk JD, Evans C, Beland SG, Kulaga S, Dykeman J, Wolfson C, Koch MW, Marrie RA. Incidence and prevalence of multiple sclerosis in Europe: a systematic review. BMC Neurol. 2013;13:128. Epub 2013/09/28.

175. Miller DH, Weinshenker BG, Filippi M, Banwell BL, Cohen JA, Freedman MS, Galetta SL, Hutchinson M, Johnson RT, Kappos L, Kira J, Lublin FD, McFarland HF, Montalban X, Panitch H, Richert JR, Reingold SC, Polman CH. Differential diagnosis of suspected multiple sclerosis: a consensus approach. Mult Scler. 2008;14:1157-74. Epub 2008/09/23.

176. Chen JJ, Carletti F, Young V, McKean D, Quaghebeur G. MRI differential diagnosis of suspected multiple sclerosis. Clin Radiol. 2016;71:815-27. Epub 2016/06/29.

177. Filippi M, Rocca MA, Ciccarelli O, De Stefano N, Evangelou N, Kappos L, Rovira A, Sastre-Garriga J, Tintore M, Frederiksen JL, Gasperini C, Palace J, Reich DS, Banwell 
B, Montalban X, Barkhof F, Magnims Study Group. MRI criteria for the diagnosis of multiple sclerosis: MAGNIMS consensus guidelines. Lancet Neurol. 2016;15:292-303. Epub 2016/01/30.

178. Polman CH, Reingold SC, Edan G, Filippi M, Hartung HP, Kappos L, Lublin FD, Metz LM, McFarland HF, O'Connor PW, Sandberg-Wollheim M, Thompson AJ, Weinshenker BG, Wolinsky JS. Diagnostic criteria for multiple sclerosis: 2005 revisions to the "McDonald Criteria". Ann Neurol. 2005;58:840-6. Epub 2005/11/12.

179. Costello F. Vision disturbances in multiple sclerosis. Semin Neurol. 2016;36:185-95. Epub 2016/04/27.

180. Pflugshaupt T, Geisseler O, Nyffeler T, Linnebank M. Cognitive impairment in multiple sclerosis: clinical manifestation, neuroimaging correlates, and treatment. Semin Neurol. 2016;36:203-11. Epub 2016/04/27.

181. Korakas N, Tsolaki M. Cognitive impairment in multiple sclerosis: a review of neuropsychological assessments. Cogn Behav Neurol. 2016;29:55-67. Epub $2016 / 06 / 24$.

182. Lee H, Bae JS, Jin HK. Human umbilical cord blood-derived mesenchymal stem cells improve neurological abnormalities of Niemann-Pick type $\mathrm{C}$ mouse by modulation of neuroinflammatory condition. J Vet Med Sci. 2010;72:709-17. Epub 2010/02/04.

183. Cologna SM, Cluzeau CV, Yanjanin NM, Blank PS, Dail MK, Siebel S, Toth CL, Wassif CA, Lieberman AP, Porter FD. Human and mouse neuroinflammation markers in Niemann-Pick disease, type C1. J Inherit Metab Dis. 2014;37:83-92. Epub 2013/05/09.

184. Lopez ME, Klein AD, Hong J, Dimbil UJ, Scott MP. Neuronal and epithelial cell rescue resolves chronic systemic inflammation in the lipid storage disorder Niemann-Pick C. Hum Mol Genet. 2012;21:2946-60. Epub 2012/04/12.

185. Swanton JK, Rovira A, Tintore M, Altmann DR, Barkhof F, Filippi M, Huerga E, Miszkiel KA, Plant GT, Polman C, Rovaris M, Thompson AJ, Montalban X, Miller DH. MRI criteria for multiple sclerosis in patients presenting with clinically isolated syndromes: a multicentre retrospective study. Lancet Neurol. 2007;6:677-86. Epub 2007/07/10. 
186. Grau AJ, Brandt T, Weisbrod M, Niethammer R, Forsting M, Cantz M, Vanier MT, Harzer K. Adult Niemann-Pick disease type C mimicking features of multiple sclerosis. J Neurol Neurosurg Psychiatry. 1997;63:552. Epub 1997/10/29.

187. Yuce A, Gumusa E, Haliloglu G, Karhan AN, Ardicli D, Demir H, Gurakan F, Topcu M. Niemann-Pick disease type $\mathrm{C}$ in the newborn period: Reflections from 10 patients. Molec Genet Metab. 2016;117 S14-S124.

188. Moyer V, Freese DK, Whitington PF, Olson AD, Brewer F, Colletti RB, Heyman MB, North American Society for Pediatric Gastroenterology H, Nutrition. Guideline for the evaluation of cholestatic jaundice in infants: recommendations of the North American Society for Pediatric Gastroenterology, Hepatology and Nutrition. J Pediatr Gastroenterol Nutr. 2004;39:115-28. Epub 2004/07/23.

189. Alobaidy H. Recent advances in the diagnosis and treatment of niemann-pick disease type $\mathrm{C}$ in children: a guide to early diagnosis for the general pediatrician. Int $\mathrm{J}$ Pediatr. 2015;2015:816593. Epub 2015/03/19.

190. McKiernan PJ. Neonatal cholestasis. Semin Neonatol. 2002;7:153-65. Epub 2002/09/05.

191. Suchy FJ. Neonatal cholestasis. Pediatr Rev. 2004;25:388-96. Epub 2004/11/03.

192. Suchy FJS. Approach to the infant with cholestasis. In: Suchy FJS, Sokol, R.J., Balistreri, W.F., (eds), editor. Liver Disease in Children. Third Edition ed: Cambridge University Press; 2007. p. 179-89.

193. Gotti G, Marseglia A, De Giacomo C, Iascone M, Sonzogni A, D'Antiga L. Neonatal jaundice with splenomegaly: not a common pick. Fetal Pediatr Pathol. 2016;35:108-11. Epub 2016/02/06.

194. Degtyareva AV, Mikhailova SV, Zakharova EY, Tumanova EL, Puchkova AA. Visceral symptoms as a key diagnostic sign for the early infantile form of NiemannPick disease type C in a Russian patient: a case report. J Med Case Rep. 2016;10:143. Epub 2016/06/03.

195. Hegarty R, Hadzic N, Gissen P, Dhawan A. Inherited metabolic disorders presenting as acute liver failure in newborns and young children: King's College Hospital experience. Eur J Pediatr. 2015;174:1387-92. Epub 2015/04/24. 
196. Yerushalmi B, Sokol RJ, Narkewicz MR, Smith D, Ashmead JW, Wenger DA. Niemann-pick disease type $\mathrm{C}$ in neonatal cholestasis at a North American Center. $\mathrm{J}$ Pediatr Gastroenterol Nutr. 2002;35:44-50. Epub 2002/07/27.

197. Pineda M, Mengel E, Jahnova H, Heron B, Imrie J, Lourenco CM, van der Linden V, Karimzadeh P, Valayannopoulos V, Jesina P, Torres JV, Kolb SA. A Suspicion Index to aid screening of early-onset Niemann-Pick disease Type C (NP-C). BMC Pediatr. 2016;16:107. Epub 2016/07/28.

198. McKay Bounford K, Ruth N, Yeung A, Lloyd C, Gray Z, Hendriksz CJ, Baumann U, Gissen P, Kelly D. A gene sequencing assay to determine the frequency of genetic conditions associated with cholestasis in neonates and infants [manuscript in preparation] 2016.

199. Herbst SM, Hinreiner S, Posovszky C, Jochum F, Rödl T, Schroeder JA, Barth TF, Melter M, Vermehren J, Hehr U. Next generation sequencing in infantile cholestatic disorders. Medizinische Genetik. 2016:120.

200. Nakamura K, Hattori K, Endo F. Newborn screening for lysosomal storage disorders. American journal of medical genetics Part C, Semin Med Genet. 2011;157C:63-71. Epub 2011/02/12.

201. Meikle PJ, Grasby DJ, Dean CJ, Lang DL, Bockmann M, Whittle AM, Fietz MJ, Simonsen H, Fuller M, Brooks DA, Hopwood JJ. Newborn screening for lysosomal storage disorders. Mol Genet Metab. 2006;88:307-14. Epub 2006/04/08.

202. Lisi EC, McCandless SE. Newborn screening for lysosomal storage disorders: views of genetic healthcare providers. J Genet Couns. 2016;25:373-84. Epub 2015/09/01.

203. Meikle PJ, Ranieri E, Ravenscroft EM, Hua CT, Brooks DA, Hopwood JJ. Newborn screening for lysosomal storage disorders. Southeast Asian J Trop Med Public Health. 1999;30 Suppl 2:104-10. Epub 2001/06/13.

204. Spiegel R, Raas-Rothschild A, Reish O, Regev M, Meiner V, Bargal R, Sury V, Meir K, Nadjari M, Hermann G, Iancu TC, Shalev SA, Zeigler M. The clinical spectrum of fetal Niemann-Pick type C. Am J Med Genet A. 2009;149A:446-50. Epub 2009/02/12.

205. Colin E, Barth M, Boussion F, Latour P, Piguet-Lacroix G, Guichet A, Ziegler A, Triau S, Loisel D, Sentilhes L, Bonneau D. In utero diagnosis of Niemann-Pick type C in the absence of family history. JIMD Reports. 2015. Epub 2015/11/14. 
206. Mackie FL, Hemming K, Allen S, Morris RK, Kilby MD. The accuracy of cell-free fetal DNA-based non-invasive prenatal testing in singleton pregnancies: a systematic review and bivariate meta-analysis. BJOG. 2017;124:32-46. Epub 2016/06/02.

207. Mak CM, Lee HC, Chan AY, Lam CW. Inborn errors of metabolism and expanded newborn screening: review and update. Crit Rev Clin Lab Sci. 2013;50:142-62. Epub 2013/12/04.

208. Jiang X, Ory DS. Towards a new diagnostic standard for Niemann-Pick C disease. EBioMedicine. 2016;4:18-9. Epub 2016/03/17.

209. Ross LF. Newborn screening for lysosomal storage diseases: an ethical and policy analysis. J Inherit Metab Dis. 2012;35:627-34. Epub 2011/12/23.

210. Yanjanin NM, Velez JI, Gropman A, King K, Bianconi SE, Conley SK, Brewer CC, Solomon B, Pavan WJ, Arcos-Burgos M, Patterson MC, Porter FD. Linear clinical progression, independent of age of onset, in Niemann-Pick disease, type C. Am J Med Genet B Neuropsychiatr Genet. 2010;153B:132-40. Epub 2009/05/06.

211. Reunert J, Fobker M, Kannenberg F, Du Chesne I, Plate M, Wellhausen J, Rust S, Marquardt T. Rapid Diagnosis of 83 Patients with Niemann Pick Type C Disease and Related Cholesterol Transport Disorders by Cholestantriol Screening. EBioMedicine. 2016;4:170-5. Epub 2016/03/17. 